NBSIR 80-2021

\title{
Report to AID on an NBS / AID Workshop on Standardization and Measurement Services
}

Edited by:

H. Steffen Peiser

Charles C. Raley

Penelope M. Odar

Office of International Relations National Bureau of Standards U.S. Department of Commerce Washington, D.C. 20234

Held October 3-21, 1978

Issued April 1980

Prepared for

Agency for International Development -ppartment of State shington, D.C. 20523

100

.456

No. 80-202] 

$\because 1$

\section{REPORT TO AID ON AN NBS/AID \\ WORKSHOP ON STANDARDIZATION AND \\ MEASUREMENT SERVICES}

Edited by:

H. Steffen Peiser

Charles C. Raley

Penelope M. Odar

Office of International Relations

National Bureau of Standards

U.S. Department of Commerce

Washington, D.C. 20234

Held October 3-21, 1978

Issued April 1980

The Workshop was conducted as a part of the program under the US/NBS Agency for International Development PASA TA(CE) 6-71

Prepared for

Agency for International Development

Department of State

Washington, D.C. 20523

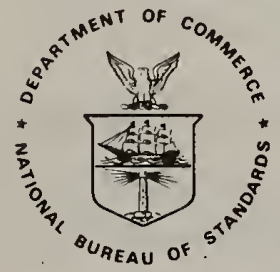

U.S. DEPARTMENT OF COMMERCE, Philip M. Klutznick, Secretary Luther H. Hodges, Jr., Deputy Secretary Jordan J. Baruch, Assistant Secretary for Productivity, Technology, and Innovation NATIONAL BUREAU OF STANDARDS, Ernest Ambler, Director 

INTRODUCTION, Mr. H. Steffen Pelser, Chief of the Office of International Relations, National Bureau of Standards, Washington, D.C., United States ............... 1

PHOTOGRAPH AND IDENTIFICATION $\ldots \ldots \ldots \ldots \ldots \ldots \ldots \ldots \ldots \ldots \ldots \ldots \ldots$

LIST OF PARTICIPANTS AND ADDRESSES .................. 4

AGENDA OF WORKSHOP $\ldots \ldots \ldots \ldots \ldots \ldots \ldots \ldots \ldots \ldots \ldots \ldots \ldots \ldots \ldots$

SUB-AGENDA-DETAILS OF VISITS TO:

Macy's New York Herald Square Training Department .......... 13

Visit to Atlanta and Georgla Tech ..................... 14

Visit to Birmingham and University of Alabama ............ 15

Southern Research Inst1tute ...................... 16

Texas Instruments, Inc. ........................ 17

CONTRIBUTED PAPER BY PARTICIPANT FROM INTERNATIONAL ORGANIZATION

STANDARDIZATION, Mr. Abdulla Fadlalla, Assistant Secretary

General, Arab Organization for Standardization and Metrology,

Amman, Jordan .................................. 19

EVENING DISCOURSES BY INVITED GUESTS

SOME OBSERVATIONS ON THE IMPLEMENTATION OF U.S. SCIENCE POLICIES,

Mr. John A. Blrch, International Consultant ............. 24

NOTES FROM THE DINNER TALK BY MR. DANIEL S. GREENBERG, EDITOR

AND PUBLISHER OF "SCIENCE AND GOVERNMENT REPORT" .......... 31

IMPORTANCE OF A STANDARDS MEASUREMENT INERASTRUCTURE IN A

DEVELOPING NATION, Dr. R. D. Huntoon, Consultant and

Deputy Director, Retired, National Bureau of Standards ...... 32

EVALUATION OF THE NBS/AID WORKSHOP

EVALUATION OF THE NBS/AID WORKSHOP ON STANDARDIZATION

AND MEASUREMENT SERVICES, $1978 \ldots \ldots \ldots \ldots \ldots \ldots \ldots \ldots \ldots \ldots \ldots \ldots \ldots$ 

Once again during the fiscal year of 1979, the National Bureau of Standards, with partial support from the U.S. Agency for International Development, offered a workshop for study of the standardization and measurement systems as they operate in the United States. These workshops have been held once every fiscal year for the past nine years. We have tried to $11 \mathrm{mlt}$ each worlishop to no more than one participant per country and have given strong preference for representatives from AID countries nominated by the AID ilissions concerned. This year's particlpants showed a good balance of the major regions and came from 16 countries (for a 11 st, see pape 4).

The 1tinerary for these workshops differs from year to year but always includes about a week within the Nis facilities and a second week at outside governmental, academic, and private sector and industrial organizations concerned with standardization, quality assurance, and measurement for research, development, or enforcement.

This year's workshop was fortunate to be recelved at the American National Standards Institute, the Polytechnic Institute of New York, at R. H. Macy and Company (the large department store), the Technical Association of the Pulp and Paper Industry, the Georgia Institute of Technology, Scientific Atlanta, the Southern kesearch Institute, the University of Alabama, Texas Instruments, Inc., the University of Texas at Dallas, and NASA's Johnson Space Center in Iouston (see agenda on pp. 7-12). All these visits were most interesting and enjoyable. It is perhaps permissible to single out the New York Polytechnic Institute at Brooklyn where we were introduced to a thoughtful effort to make a high-level academic program relevant to specific needs of students from less industrialized regions of the world. We were all greatly impressed by the meaningful testing that liacy's conducts on behalf of its customers. The warmth of Southern hospitality which the workshop group recelved in Atlanta and Birmingham was equaled by the strong technical content of all visits. The last two days in Texas gave a glimpse of the smallest and largest scales of high technology at Texas Instruments and NASA.

Two special features of this NBS/AID lorkshop need special mention. First was the opportunity to attend the annual convention of the National Conference of Standards Laboratorles. It is a forum of. laboratories in the public and private sectors exchanging views and news on methods of testing and standardization with emphasis in the high technology flelds. By recent membership decisions, the NCSL has opened its doors to interested laboratorles abroad. It is the view of the NBS staff that this membership could become a major mechanism for transfer of infrastructure technology to less developed countries.

For the second year, the NBS/AIn Workshop was itself host to a speclal seminar designed to assist the preparation for the U.N. Conference on 
Sclence and Technology for Development. This year's topic was "The Technological Knowledge Base for Industrlalizing Countrles." Its proceedings are already in print (NBS Speclal Publication 543, April 1979). It contalns the contributed papers of participants in the Seminar from abroad Including those of the Workshop. Their papers would otherwlse have been a feature of this report.

Speclal evening discourses presented to the Workshop outside the NCSL and UNCSTD meetings are reported in this publication. The last and longest is Dr. Robert Huntoon's paper $(p, 32)$. It is thought provoking and is espectally recommended for close study. Mr. John BIrch's remarks ( $p, 24)$ are those of a distingulshed U.S. Forelgn Service Officer, who in recent years has made international relations in sclence and technology his speclalty. Assistant Secretary General of the Arab Leagie Organization for Standardization and Metrology, Vir. Abdulla M. Fadlalla, is especlally well qualifled to write on standardization (p. 19) as seen from a group of nations that aim to catch up rapidly into modern advanced technology. Mr. Daniel Greenberg's remarks are only sumarlzed (p. 31), He 18 a widely respected, often critical, observer of the Washington scene concerned with sclence and technology and their international ramifications.

I cannot conclude this introduction of this iJBS/AID Workshop report without expressing the appreciation of NBS not only to AID for having partly supported these workshops for almost ten years, but also to the more than 40 countries that have participated actively in this program. Although they have been popular, well evaluated, and always oversubscribed, these workshops are not likely to be repeated in the years immediately following the workshop here reported. It remalns my hope that this or a similar activity will be reintroduced in lacer years because the United States should in 1 ts own Interests explain to frlends abroad how our complex standardization systems operate. Much International trade depends on them, and that trade, if well conducted, benef1ts all partles.

H. Steffen Pelser

February 1980

(contributed after his retirement from NBS) 


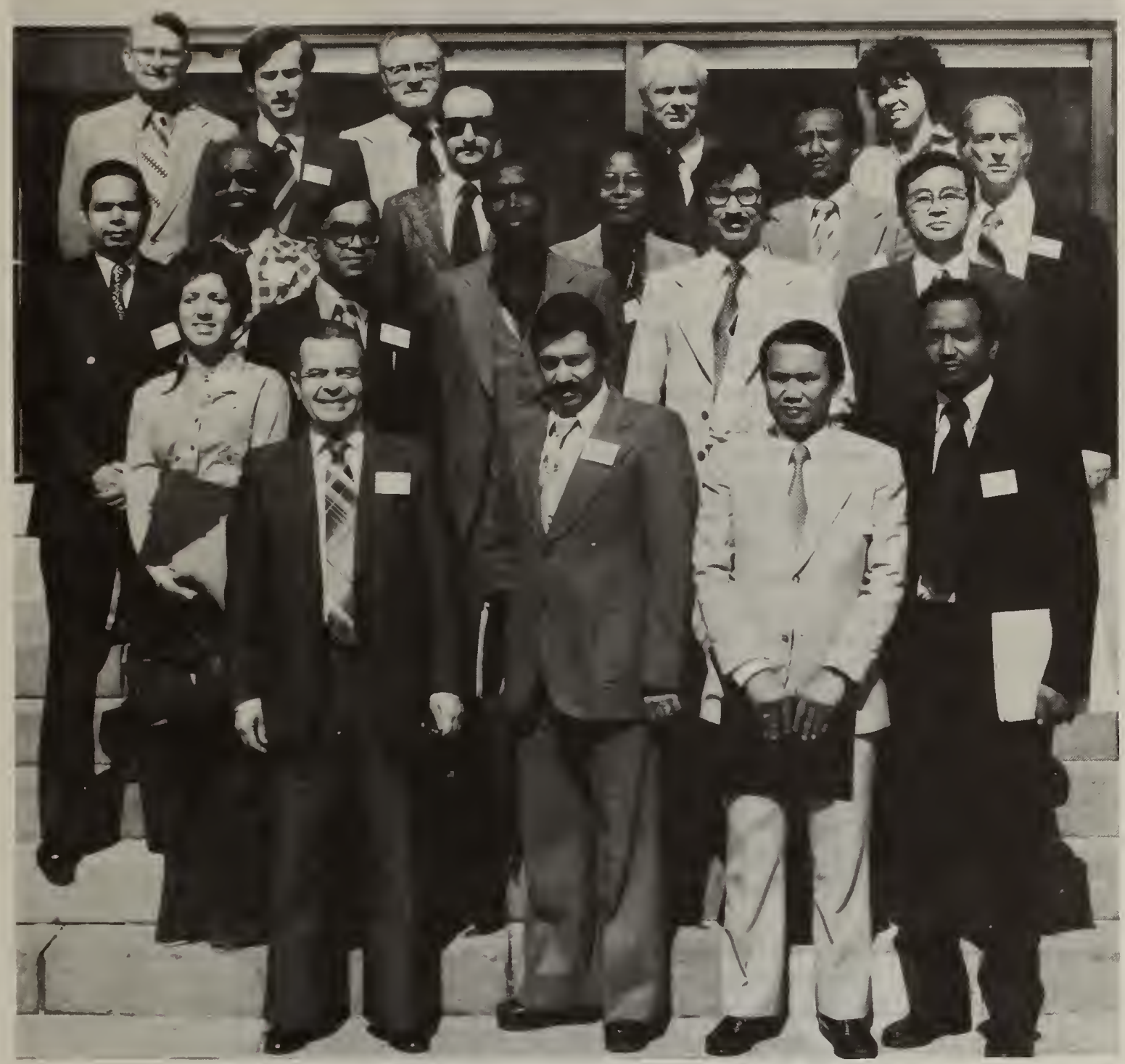

Photograph identification: (left to right)

5th step: Mr. R. Walleigh, Mr. C. Raley, Mr. B. Gutterman, (top row) Adm. J. Waeny, Mrs. P. Odar

4th step: Dr. J. Tudor, Mr. H. Mazza, Mrs. L. Lawrence, Mr. A. Fadlalla, Mr. S. Peiser

3rd step: Dr. K. Chandra, Mr. T. Rajaraman, Mr. J. Owino-Okwero, Dr. K. Khalaf, Mr. D. Kim

2nd step: Mrs. M. de Chan

1st step: Mr. R. Bouhalila, Mr. R. Halteh, Mr. Gandi, Mr. A. Suliman (bottom row) 


\section{PARTICIPANTS \\ 1978 NBS/AID WORKSHOP \\ ON STANDARDIZATION AND MEASUREMENT SERVICES \\ (alphabetical by country)}

\section{National Representatives}

1. Mr. Horacio Federico Mazza

Chief, High Frequency Measurements and Calibration

Electronic Metrology Division

Inst1tuto Nacional de Tecnologia Industrial (INTI)

Leandro N. Alem 1067 , pisos $5^{\circ}, 6^{\circ}$ y $7^{\circ}$ -

1001 Capital Federal

Buenos Alres, Argentina

2. Dr. Jose L. Tudor

Chief, Laboratory Section

Barbados National Standards Institute (BNSI)

Flodden, Culloden Road

St. Michael, Barbados

3. Adm. Jose Carlos de Castro Waeny

Measurement Assurance officer

Instituto de Pesquisas Tecnologicas (IPT)

C.P. 7141

01000 Sao Paulo SP, Brazil

4. Mrs. Lorna Lawrence

Senior Scientific officer

Guyana National Bureau of Standards

National Science Research Council Guyana

44 Pere St. Kitty (P.0. Box 689)

Georgetown, Guyana

5. Dr. Kailash Chandra

Sclentist-in-Charge

Electrical and Electronic Standards

National Physical Laboratory

liillside Road

New Delh1-110012, India

6. Mr. Gand1

Secretary, Yayasan Dana Normal1sasi Indonesia (Indonesian Standardization Funds Foundation)

Jalan Braga 40

Bandung, Indonesia 
7. Mir. Remon Halteh

Head, Quality Mark Division

Directorate of Standards

Minlstry of Industry and Trade

P.0. Box 2019

Amman, Jordan

8. Lir. J. E. Ow1no-Okwero

Senfor Standards officer

Clvil Engineering Department

Kenya Bureau of Standards

P.O. Box 10610

Na1rob1, Kenya

9. ir. Kim, Dong Ho

Chief, Llectric and Electronics Lepartment

National Industrial Research Institute (NIRI)

Industrial Advancement Administration

MInIstry of Commerce and Industry

219 kar1bong-dong Yungdeongpo-ku

Seoul, Korea

10. Dr. I. M. Qurash1

Director General

Appropriate Technology

Development Organization

1-A, Street $47 \mathrm{th}$, F. $7 / 1$

P.0. Box 1306

Islamabad, Pakistan

11. Nirs. Naricela Ferrer de Chan

Director, Comision Panamena de

Normas Industriales y Tecnicas (COPANIT)

Apartado Postal 9658 - Zona 4

Panama C1ty, Panama

12. Ir. Whaled Y. Al-Khalaf

Director General

Saud1 Arablan Standards Organization (SASO)

P.0. Box 3437

Rlyadh, Saud1 Arabla

13. Mr. Abdel Gadir Suliman

Director General

Department of Standardization

and Quality Control

Ninistry of Industry

P.0. Box 2184

Khartoum, Sudan 
14. Mr. Thlagarajan lafaraman

Techn1cal Manager

Tanzanta Bureau of Standards

P.O. Box 9524

Dar es Salaam, Tanzania

15. Mr. Nidha Bouhal11a

Director

Laboratolre Central

llontfleury, Tue Dr. Braquehaye

Tun1s, Tunisia

International Representative

16. Mr. Mbdulla M. Fadlalla

Assistant Secretary General

Arab Organlzation for Standardization

and Metrology (ASMO)

P.O. Box 926161

Amman, Jordan 


$$
\begin{aligned}
& \text { National Bureau of Standards } \\
& \text { Agency for International Development } \\
& \text { WORKSHOP ON STANDARDIZATION AND MEASUREILNT SERVICES } \\
& \text { AS PRACTICED IN THE UNITED STATES } \\
& \text { October } 3 \text { - October 21, } 1978
\end{aligned}
$$

October 3, Tuesday (Optional)

$$
\text { AM - PM , Arrive Galthersburg, Maryland, U.S.A. }
$$

October 4, Wednesday (Optional)

$$
\begin{array}{ll}
\text { 8:15 AM } & \begin{array}{l}
\text { Greeting, Mr. I. S. Peiser } \\
\text { Chief, Office of International Relations }
\end{array} \\
\text { 9:00 AM - } & \text { National Conference of Standards Laboratories } \\
\text { 4:45 PM } & \\
\text { 7:00 PM - } & \text { Conference Banquet } \\
\text { 9:00 PM } &
\end{array}
$$

October 5, Thursday (Optional)

9:15 AN - National Conference of Standards Laboratories $4: 45 \mathrm{PM}$

October 6, Friday (Optiona1)

9:15 AM - National Conference of Standards Laboratories 12:30 PM

1:30 PM - Execut1ve Session, Mr. R. S. Walleigh

5:00 PM Senior Adviser for International Affairs

October 7, Saturday (Optiona1)

AM Travel to New York, liew York

PII Free

October 8 , Sunday

AM Free

8:00 PM Briefing Session 
October 9, Monday

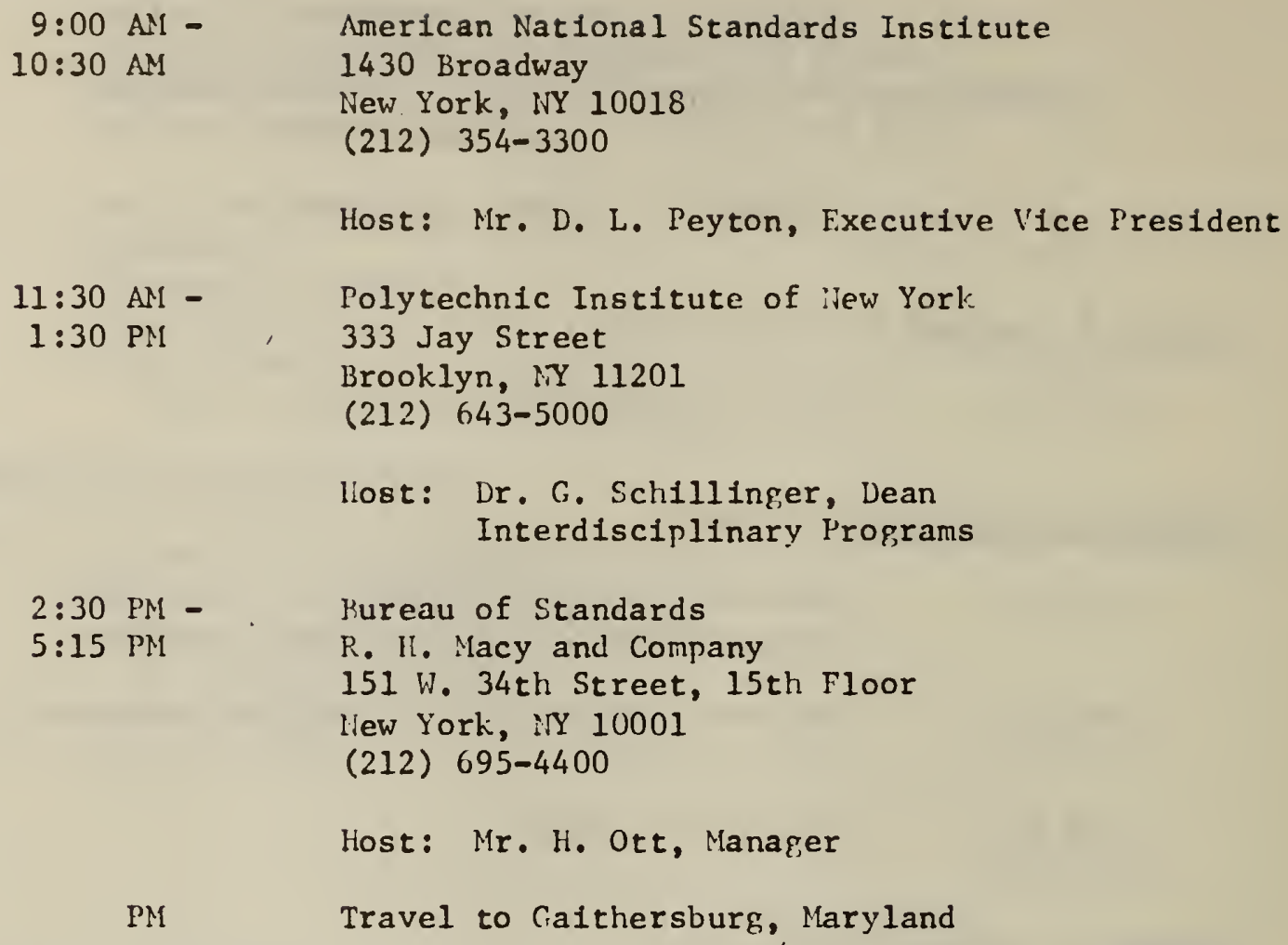

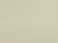

October 10 , Tuesday

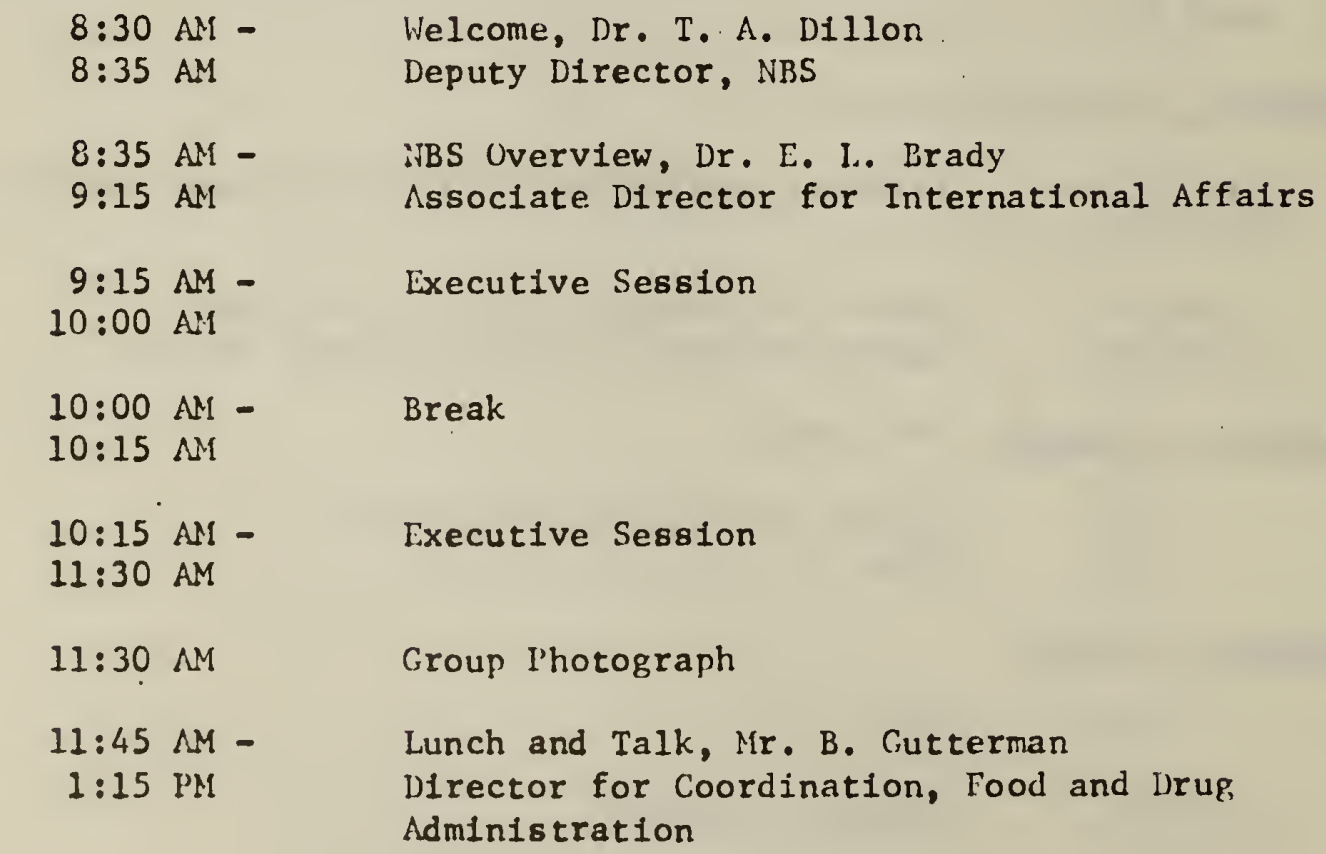

$8: 30 \mathrm{AM}-$
$8: 35 \mathrm{AM}$
$8: 35 \mathrm{AM}-$
$9: 15 \mathrm{AM}$
$9: 15 \mathrm{AM}-$
$10: 00 \mathrm{AM}$
$10: 00 \mathrm{AM}-$
$10: 15 \mathrm{NM}$
$10: 15 \mathrm{AM}-$
$11: 30 \mathrm{AM}$
$11: 30 \mathrm{NM}$
$11: 45 \mathrm{NM}-$
$1: 15 \mathrm{MM}$

Welcome, Dr. T. A. Dillon

Deputy Director, NBS

iBS Overview, Dr. E. L. Brady

Associate Director for International Affairs

Executive Session

Break

Executive Session

Group Ihotograph

Lunch and Talk, Mr. B. Gutterman

Director for Coordination, Food and Irug, Administration 
$1: 30$ PM -

5:00 PM

$7: 00$ PM -

$9: 30$ PM
National Engineering Laboratory

Session I

Dinner and Talk, Mr. D. S. Greenberg

Editor and Publisher, "Science and Government Report"

October 11, Wednesday

\section{$9: 00$ AMI - \\ $11: 30 \mathrm{AM}$ \\ $11: 45$ AM - \\ $1: 15 \mathrm{PM}$ \\ $1: 30 \mathrm{PM}-$ \\ 5:00 PM}

$7: 00 \mathrm{PN}-$

$9: 30 \mathrm{PM}$

Uctober 12 , Thursday

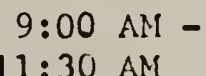

$11: 30 \mathrm{AM}$

$11: 45 \mathrm{NM}-$

$1: 15 \mathrm{PM}$

$1: 30 \mathrm{PM}-$

$2: 15 \mathrm{PM}$

2:30 PM -

$3: 15$ PM

3:30 PN -

$3: 45$ PM

$3: 45 P M-$

$5: 00 \mathrm{PM}$

$7: 00 \mathrm{PN}-$

$9: 30 \mathrm{PM}$

October 13, Friday

$9: 00$ AN -

$11: 30 \mathrm{AM}$
National Engineering Laboratory

Session II

Lunch and Talk, Mr. F. Post

Consultant, National Technical Information

Service

liational Measurement Laboratory

Session I

Dinner and Talk, Mr. J. Birch

International Science and Technology Consultant

National Measurement Laboratory

Session II

Lunch and Talk, Mir. J. Rabinow

Chief Research Engineer, NEL

Library Information Services, Ns. I. Patrias Chief

Instrument Shops Division, Mr. D. S. Bettwy Chief

Break

Cooperative Technology

Dr. H. E. Sorrows, Technology Adviser

Dinner and Talk, Dr. I. D. Huntoon

President, Measurement, Tvaluation and Management Organization

Institute for Computer Sciences and Technology Mr. M. Z. Thornton, Acting Director 
$\begin{array}{ll}\text { 11:45 AM - } & \text { Lunch } \\ 12: 30 \mathrm{PM} & \\ \text { 1:30 PM - } & \text { Weights and Neasures Section } \\ 3: 30 \mathrm{PM} & \text { Department of Agriculture } \\ & \text { State of Maryland } \\ & \text { College Park, MID } 20742 \\ & \text { (301) 454-3551 } \\ & \text { Host: Mr. C. Stockman, Metrologist }\end{array}$

October 14, Saturday

$A M-P M \quad$ Free

October 15 , Sunday

AN - Pll Tree

October 16 , Monday

$9: 15$ Alf -

5:00 PM

Seminar, "The Technological lnowledge Dase for Industrializing Countries"

5:30 PM -

$8: 00 \mathrm{PM}$

October 17 , Tuesday

$9: 00$ AM -

5:00 PN

$5: 15$ Pll -

5:45 PM

PM

October 18 , liednesday

$9: 00 \mathrm{AM}-$
$10: 00 \mathrm{AN}$

$10: 45$ AM -

1:45 PM
Technical Assoclation of the Pulp and Paper Industry

1 Lunwoody Parl:

Atlanta, C.A 30341

(404) 394-6130

Georgia Institute of Technology

Atlanta, CA 30332

(404) 894-2308

llost: Ir. K.. Stepliens, Professor 


$$
\begin{aligned}
& \text { 2:15 FM - Scientific Atlanta } \\
& \text { 4:15 PH } 3845 \text { Pleasantdale Foad } \\
& \text { Atlanta, GA } 30340 \\
& \text { (404) 449-2000 }
\end{aligned}
$$

October 19, Thursday

$$
\begin{aligned}
& \text { 8:30 Al - Southern Research Institute } \\
& \text { 11:30 NH , } 20009 \text { th Avenue South } \\
& \text { Birminglam, AL } 35205 \\
& \text { (205) 323-6592 } \\
& \text { Public P.elations } \\
& \text { 12:00 IN - . Lniversity of Alahama in Pirmingham } \\
& \text { 4:30 Pll Nortimer Jordan llall } \\
& \text { Iifmingham, AL } 35294 \\
& \text { (205) } 934-4011 \\
& \text { liost: Dr. R. V. Trenct, Assistant } \\
& \text { to the President }
\end{aligned}
$$

Uctober 20 , Friday

$$
\begin{aligned}
& 8: 30 \mathrm{All}- \\
& 1: 00 \mathrm{PIL} \\
& 1: 30 \mathrm{PH}- \\
& 4: 00 \mathrm{PH}
\end{aligned}
$$

PM

9:00 PM 10:00 PM
Texas Instruments, Inc. (13500 iortl Central Lxpressway) P.O. Lox 225474 Iallas, TX 75265

Host: I!r. H. Post, llanager, Financial lielations

University of Texas at lallas Lox 688

Eicilardson, TY 75080

llost: Dr. F. S. Johrison Executive lean of Graduate Studies and Research

Travel to Houston

Closing Dinner 
October 21, Saturday

$8: 00 \mathrm{MM}-$

9:00 $\mathrm{NM}$

9:00 AN! -

11:00 N!
Johnson Space Center

Calibration Laboratory

llouston, Texas 77058

(713) 483-2791

Host: Ir. T11 ghman

General lour - Johnson Space Center

Conclusion of Worlishon 


\author{
(DETAILED AGLINDA) \\ MACY*S INEW YURK \\ HERALD SQUARE TRAIIING IEPART:IEIT
}

Honday, October 9, 1978

\begin{tabular}{|c|c|c|}
\hline TIME & SPEAKER & TOPIC \\
\hline $2: 30-3: 30$ & $\begin{array}{l}\text { :ir. II. ott } \\
\text { lianager, } \\
\text { Bureau of } \\
\text { Standards }\end{array}$ & $\begin{array}{l}\text { Tour of. Bureau } \\
\text { Discussion of: } \\
\text { - Testing methods for softgoods } \\
\text { and hardgoods } \\
\text { - Quality Control } \\
\text { - Covernmental Fegulations } \\
\text { Conmunicating to buyers } \\
\text { Paper work } \\
\text { - Merchandising Practices } \\
\text { Both good and bad } \\
\text { - Labeling }\end{array}$ \\
\hline $3: 30-4: 30$ & $\begin{array}{l}\text { Hs. K. Brewster } \\
\text { Ilanager, } \\
\text { II.S. Training }\end{array}$ & $\begin{array}{l}\text { Tour of Macy*s llerald Square Selling, } \\
\text { Floors: } \\
\text { - Domestics on } 6 \\
\text { - Children's on } 5 \\
\text { - lifses on } 3 \\
\text { - The Cellar }\end{array}$ \\
\hline $4: 30-5: 15$ & $\begin{array}{l}\text { Mr. H. Utt } \\
\text { is. K. Brewster }\end{array}$ & $\begin{array}{l}\text { Location: } 15 \text { th Floor Conference Room } \\
\text { - Questions and Answers }\end{array}$ \\
\hline
\end{tabular}




\section{VISIT TO ATLANTA AND GEORGIA TECH}

Wednesday, October 18, 1978

9:00-10:15 a.m., "Overview of TAPPI's Activities"

Technical Association of the Pulp and Paper Industry

7 Dunwoody Park, Atlanta, GA 30341 (404) 394-6130

liost: Mr. Falph klucken, Sentor Division Administrator

10:45-11:30, "Approprlate Technology," Room 303, Baker Bldg., Dalney St.

Speaker: Mir. Ross Hammond, Director

Office of International l'rograms

Engineering Experiment Station

Georgla Institute of Technology

Atlanta, GA 30332 (404) 984-3800

$11: 30-12: 15$, "CPSC's Current Program"

Speaker: Nr. George Lester, Director of Operations

CPSC Atlanta Area Office

1330 W. Peachtree Street

Atlanta, GA 30309 (404) 881-2231

12:15-12:45, "Georgla Tech's MSIE. (Industrialization) Program" Speaker: Dr. David E. Fyffe, Professor

Industrial \& Systems Engineering

Ceorgia Institute of Technology

Atlanta, GA 30332 (404) 894-2310

2:15-4:15, Tour of Calibration and Instrumentation Labs

Sclentific Atlanta

3845 Pleasantdale Rd.

Atlanta, GA 30340

Guldes: Ms. Ruby Erkkinen, International Marketing Coordinator

Ir. Bill Bonltla, Export Manager, Instrumentation Division (404) 449-2239, 449-2000

Coordinator of Program: Dr. K. S. Stephens, Industrial \& Systems

Engineering, Georgla Tech, Atlanta, GA 30332

(404) $894-2308$ 
(DETAILED ACENDA)

VISIT TO BIRMINGHAN AND UNIVERSITY OI ALABAMA

Thursday, October 19, 1978

Hosts: Dr. Robert W. French, Assistant to the President University of Alabama in Hirmingham

Mr. David Hunter, Trade Speclallst, USDOC

Mr. J. H. Strickland, Nanager Public Relations

Southern Research Institute

October 19,1978

$8: 30-11: 30 \mathrm{a} \cdot \mathrm{m}$.

12:00 Noon

1:30 p.m.

$2: 20 \mathrm{p} \cdot \mathrm{m}$.

3:00 p.m.

$3: 45 \mathrm{p} . \mathrm{m}$.
Southern Research Institute

Luncheon at Plaza South Hotel, Unlversity Room llost: Dr. Robert W. French, Assistant to the l'resident, University of Alabana in Birmingham

Presentation by Dr. Robert L. Settine, Associate Professor of Chemistry and Director of the Gas Chromatograph/ilass Spectrometer Center, University of Alabana in Birmingham

Presentation by $\mathrm{Dr}$. Louis C. Sheppard, Associate I'rofessor, Department of Surgery, University of $\Lambda$ labama in Birmingham

Presentation by Dr. Seymour S. Vest, Chairman and Professor, Department of Englneering B1ophysics, University of Alabama in Birmingham

The group will walk to the 8th Floor Conference koom of the Dental Bullding for a briefing by Mr. J. Daniel Lynn, Spectal Assistant to the Chalrman, Department of Microblology, University of Alabama in Birmingham. Following the briefIng, the group will tour the cell Culture Fac1lity. 


\section{SOUTHERN RESEARCH INSTITUTE \\ 2000 Ninth Avenue South \\ B1rmingham, Alabama 35205 \\ (205) 323-6592}

Thursday, October 19, 1978

-Introduction:

James H. Strickland, Manager of Public Relations

-Overvlew of Southern Research Inst1tute:

Sabert Oglesby, Jr., Vice President and

Director of Englneering and Applied Sclences Research

-Particle Size Measurement, Other Alr Pollution Control Research:

Kenneth M, Cushing, Head, Aerosol Physics Section

--Standards for Measuring Resistivity In Particulates:

Dr. Roy E. Blckelhaupt, Head, Ceramics Section

- Character1zation of Materlals:

H. Stuart Starrett, Head, llechanics DIvision

-Metallurgy Research:

Dr. Charles E. Bates, Head, Metallurgy Section

-Cancer Research:

Dr. Salah El Dareer, Senlor Pharmacolog $18 t$, Blochemical Pharmacology Division

--Tour of Research Laboratorles:

Including comments by:

Dr. Thomas H. Corbett, Head, Tumor Blology and Treatment Section

Dr. Herbert C. Miller, Head, Analytical Chemistry' Section

Ruby James, Program Manager, Organic Analysis 


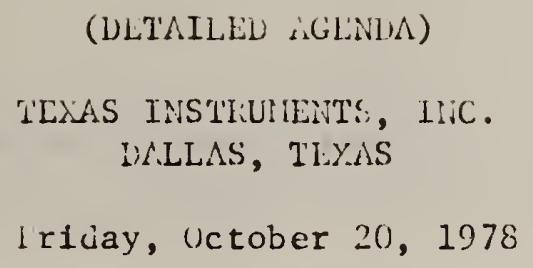

$12: 15 \quad$ Lunch

liichard lijggins 



$$
\begin{gathered}
\text { Mr. Abdulla Fadlalla } \\
\text { Assistant Secretary General } \\
\text { Arat Organization for Standardization and Netrology } \\
\text { Amman, Jordan }
\end{gathered}
$$

Member countries of the International Standardization Organization (ISO) will be celebrating the World Standards Day while we are participating in this NBS/AID Workshop on Standardization and Measurement Services. In fact, I would like to stress that by organizing this Workshop in October and by selecting some standardization personnel to take part, this in itself is a way of celebrating World Standards Day.

When this day approaches, we usually recelve some comments and views questioning what standardization is and why standardization has importance.

In an attempt to put a simple reply to these questions, one should deal with the subject by considering the parts that comprise standardization, namely:

$$
\begin{aligned}
& \text { 1. Metrology } \\
& \text { 2. Standards } \\
& \text { 3. Quality Control and certification }
\end{aligned}
$$

\section{Metrology}

Netrology is the activity of making measurements by using physical standards, and as such, it impinges both on all human endeavors and on all societies. It is essential to trade. It is fundamental to science. So it is the basis of the whole subject of standardization. Simply stated, the economy of the country is entirely dependent on metrology, the business of weighing or measuring. From the viewpoint of the simple consumer, the importance arises from his wish to be assured that equity exists in the marketplace, that he is getting the right and correct quantity for the price he is paying; so metrology must be the basis for any developmental body and for any attempt to create an able standardization body in a developing country. In this respect, I would like you to share with me the foy of reading just a small part of Mr. John Quincy Adams' report to the U.S. Congress in 1821. This in part reads:

\footnotetext{
"Weights and measures may be ranked among, the necessaries of 11 fe to every individual of human society. They enter into the economical arrangements and dally concerns of every family. They are necessary to every occupation of human industry; to the
} 
distribution and security of every species of property; to every transaction of trade and commerce; to the labors of the husbandman; to the ingenulty of the artificer; to the studies of the philosopher; to the researches of the antiquarian; to the navigation of the mariner, and the marches of the soldier; to all the exchanges of peace, and to the operations of war. The knowledge of them, as in established use, is among the first elenents of education, and is often learned by those who learn nothing else, not even to read and write. This knowledge is riveted in the memory by the habitual application of it to the employments of men throughout $11 \mathrm{fe} . "$

This quotation from the report of the Secretary of State to this U.S. Congress in 1821 more than 150 years ago clearly 1llustrates the importance and the application of weights and measures. I quoted this paragraph to support my argument that weights and measures are not only important in the marketplace but are also without doubt very essential in all activities in life. The existence of a strong metrological facility in every country is important for proper development; it provides callbration services for industry, facilitates comerce, and transaction of goods.

Metrology in relation to standardization activities forms the basis for writing standards for speclfications and quality control.

\section{Standards}

The second subject is that of standard specifications. ISO defined standardization as "the process of formulating and applying rules for an orderly approach to specific activity for the benefit and with the cooperation of all concerned, and in particular, for the promotion of optimum overall economy taking due account of functional conditions and safety requirements."

It is clear that the approach lald by ISO in this definition is the same for every country, b1g or small, developed or developing, although the Interests may differ according to the degree of development.

Standardization assists developing countries in several ways since it supports forelgn trade. As a number of the developing countries are still exporters of raw materials and may continue to be so for some time to come, the existence of standards helps producers and exporters to provide what is expected by the international market, thus obtalning a better return.

In the case of Industrial production, since standardization is the outcome of the technological progress leading to better production, it would be far better if developing countries could make use of this advantage and acquire the experience of the industrialized countries by glving priorlty and support to standardization efforts. It is 
uncerstood that standardization bodies and societies in acivanced countries nay be set up as a necessity to inciustrial developrent or as an outcome of Industrialization, but in developing courtries, it is advocated that standardization bodles should be well recognized and strengthened, not only to go in parallel with industry but also to precede Industrial growth.

In laying down natlonal development flans, standardization should be given its proper dimension and should be considered as an interral part of the national plans. A strong and able standards body would be of immense service to the planning, authority as it will male sure that what has been planned 18 really executed and 1mplemented according to the correct requirements, that purchase of materlal, services, and production is done according to the set and agreed standards, thus avolding waste, surplus, or faulty materlals and equipnent. Products w1ll be readily acceptable both internally or externally.

According to reports from some developing countries, this picture exists only in theory while in practice it is not so. Standards bodles have not yet achieved full recognitfon by the concerned authorlties nor is use made of the standards produced. The obvious result would be production and services of Inadequate quality resulting in an outcry of the public condemning local production. lience, the importance of standardization arises then from the fact that it has profound importance on the productivity and efficiency of every producing concern, and without $f . t$, development is hampered. If we agree that standards assist developing countries in establishing a program for proper selection, imports, and adaptation of forelgn technology, that 1 t reduces waste, and achieves overall economy $1 n_{1}$ production and consumption, that 1t is a safefuard against lor. qual1ty, allows interchangeability, and helps in varlety reduction, then the subject matter need not be emphasized further.

\section{Qual1ty Control and Certification}

Standardization w1ll gain more recognition if it is assoclated with a program of quality. In Industry the term quality control is now being revised and a more accepted term tends to be preferred; the term 1s quality assurance. The reason for such replacement is that the term quality control implies a check alone on the final product while quality assurance Indicates that checks should take place at all the different stages of production including the initial raw material. For the desired standard planned from the start for the final product, quality control remains the term in use.

The 1mportance of quality control and assurance in developing countries 11 es in giving a proper weight to the standards produced by the standards body. The importers of elther finlshed products or raw materials shall be confident of the quality of their 1mports, elther for direct sale to the market or for processing. It safeguards quality during manufacture, in warehousing, and in distribution trade. 
It assures safety in use of equipment, appliances, and also in foods, drugs, and mediclnes.

\section{Standards Laboratories}

Metrology, standards, and quality checks will only be effective and of service to the economy of any one country if a well equipped laboratory for testing and research is created. Then it will be possible to have a third party assurance or what is accepted to be called certification or kite.

\section{Benefits of Standardization}

The economy of any one country can draw a lot of benefits from standardization if the whole subject of standardization is given recognition.

The benefits that may accrue from standardization could be summarized very briefly in the following:

Use of local materlals--by application of standardization the local materlal supplier shall be obliged to deliver his material in accordance and conformity with the set standards, and there would be no need nor justification for importation of this materlal from outside the country. The adoption of this method in one activity will encourage others to follow sult, and this, of course, will ultimately lead to a wider use and utilization of the country's resources.

\section{Transfer of Technology}

The role of standardization in the transfer of technology is a wide subject for discussion, and as a matter of fact, it was dealt with in many seminars and conferences. It 18 st1ll and shall be an interesting subject for discussions. Transfer of technology may take different shapes or forms. It may involve a complete transfer of a process or processes or part of 1t. It may involve just knowledge of a product technology or knowledge of the process to be used with detalls of the engineering practice. It may involve the training of personnel for a certain job.

However, the role of standardization in such transfer remains to be an important factor to safeguard an adequate and effective flow of knowledge from one country to another.

\section{The Benefit to the Consumers}

Standardization helps consumers--when products intended for human use are put up for sale. It is not easy for an average consumer to fudge the quality of the goods he is intending to purchase. If It is an electrical appliance, he is not able to assure himself of its rellability and safe use. Standardization solves this problem by 
first of all assuring the material, the flow of production, testing, and quality control. The following step which assures the buyer that the quality he is buying satisfies the minimum requirements and that It is safe and reliable, is what is called certification or the quality mark. This puts the standardization body in the place of a guarantor for the quality and rellability.

Informative labeling is also another way of helping the consumer to assure himself of the ingredients of which the product is made, the date of manufacture, and in some cases, the expiry date. Informative labeling also helps consumers to follow certain instructions, e.g., keeping the product cold or warm, etc.

These are but a few remarks that are intended to clarify some questions that we are usually being asked. I thought of putting them before the participants as headlines for discussion. 


\title{
SOME UBSERVATIONS ON THE IIPLENENTATION \\ UF U.S. SCIENCE POLICIES
}

\author{
by \\ is. John A. virch \\ Iuternational Consultant
}

Lis good friend and colleague, uteffen leiser, was lind enough to ask: me to speak to you' this evening briefly and informally on several of my experiences as a retired officer of the united States Foreigr. Service who came to the general field of science and technolosy after 30 years in a wide variety of forelgn policy matters. These included economic affairs, international finance, trade, and to some extent, aid, shipping, and civil aviation. liy job was, of course, to represent the interests of the United States abroad in nany of its varied aspects.

Lrider these circumstances, I wondered what I could possibly say that vould be of interest to a distinguisiec group of scientists whose individual disciplines and interests are, to put it mildly, usually iay over my head. Lut my ceciston to accept a post as forelgn affairs adviser to the Assistant sicretary for Sicience and Iechnology at the Jepartment of Conmerce in 1970 was based on the feeling that I could nake some contribution to the growing area of international science relations. In today's circumstances, science has uncergone an increasing trend toward "institutionalization," that is to say, many countries, including the linited States, have negotiated a number of bilateral agreements which set a general framework for the conduct of scientific cooperation in mutually arreed fields, such as joint research and projects in selected areas, exchange of information and results, sharing of certain types of facilities, exchanges of scientists, symposia, etc.

If you will forgive a personal note, I have selected two areas in wich I have worked and interacted with scientists and policy-making officials. These may well be outside your normal day-to-day interests, but there may be tines when your views vill be sought (and so doubt have been sought) on issues relating to the matters I will discuss. The areas selected for this discussion with you are:

(1) the circumstances which led to united states menbership in the International urganization of Legal ietrology (OIIL), and (2) a review of United states-Japan scientific and technological relations at the , overnment-to-government level.

The UIM was founded in 1955 largely on Furopean initiative to promote intergovernmental cooperation in the field of lesal metrolosy, which broadly relates to the compatibility of standards of measurement and the legislation and government regulations wilich may affect sucn standards of measurement. l'ossessing organizational status, $i I$ I has 
a Secretariat in Paris which acts as a documentation center. Its members meet periodically, establish expert comittees, and recommend uniform international requirements for scientific instruments used in industry and commerce. UIML works out nodel laws and regulations for consideration by member countries. By 1974 OIIL had 43 members, and I note that a number of you here this evening represent countries which are active members of OIM, namely India, Indonesia, Korea, Tunisia, and possibly others. But it is not my purpose to discuss OIML in deta11. NBS is far more skilled than I to do this. My earlier participation in helping to bring about United States membership is the subject of my comments.

By 1970, a good many years after UIM was founded, U.S. participation was stalled on dead center. Tils certainly was not tecause of a lack of interest, but mainly because L.S. pollcy had dictated that $L . S$. representation in international technical organizations should be established within the framework of the InIted Wations. When I accepted an international advisory position with the Department of Commerce official concerned with matters of this kind, I found with some misgivings that my first task was to attempt to secure a reversal of this long-standing policy. It was rather like tilting at windmills--and all of you have done this at times, I am sure.

First, it was clear that the Department of State, whicl bears constitutional responsibility for the conduct of our foreign affairs, really had little interest in changing the policy against membership in new organizations outside the L.iv. framework. The policy had been established, and that was that. I do not mean this as a criticism. After all, new organizations are costly. If they are formed by treaty, advice and consent of the Congress must be sought, altogether a rather formidable effort.

Second, in a L.S. domest1c sense, OII had taclt support but no vocal constituency. A few organizations understood the value of U.S. membership but had mounted no real effort to bring it about.

So we stood in 1970 at a standstill on UIIL, notwithstanding solid support from $\mathrm{LBS}$ and from a few private organizations which were concerned with the effect of OIML recommendations on U.S. exports. We felt that we knew the problem, but the solution seemed elusive.

I therefore chose a straight-forward, pragmatic effort. A lengthy paper was developed for the Department of State explaining in detail the advantages of U.S. membersh1p, as well as its actual financial costs. Th1s was sent to the part of the State Department responsible for International organizations. The result, I am sorry to say, was no action, no response. lie began to wonder if we had falled to make a convincing case. Perhaps we were simply overcome by our own rhetoric and arguments. Again, I mean no criticlsm--a policy had been 
established, and we were trying to change it. The ball, as it were, was still in our court.

After considerable effort, many phone calls, etc., we found that our careful, and we thought, we1l-reasoned letter to the Department of State had been relegated to the files, and there seemed to be no intention even to respond or to relterate the long-standing negative attitude toward U.S. participation in OIIL. We were obviously not satisfled and decided to bring the matter to a head by a discussion, or confrontation if that seemed to be necessary, with the most senior official at State who would be responsible for recommending a change in policy. When the time arrived for our discussion, we found that State not only did not regard OIM as a particularly important organization, but it was not at all keen about undertaking the considerable effort which would be involved in presenting the matter formally to the Congress (in this case, the Committee on Foreign helations of the Senate), since ('.S. particlpation would Involve a comitment by treaty. In addition, state was concerned about the budgetary requirements of participation in yet another organization.

Wie countered with our strongest argument that the agency of the Government most directly concerned with oIN should at least have an opportunity to present the entire matter to the Congress. If the Congress turned us down, that decision would be final, but at least the effort would have been made.

That final argument prevalled. The State Department shortly thereafter agreed to seek Congressional approval, and on fugust 11 , 1972, the Senate gave Its advice and consent to the accession of the United States to the Convention establishing OIM. The viational Bureau of Standards was subsequently delegated responsibility for nanaging U.S. involvement.

I mentioned earlier the growth of our bllateral relations in eclence and techology. The United States now has 18 or 20 bilateral agreements with other countries governing in general the conditions for scientific cooperation, exchanges of scientists, joint activities and studies, etc. These agreements vary in scope and detail, of course--some provide for stending bi-national commissions, others do not. Since time will not permit me to go into this subject in detail, I have decided to talk to you about a relationship whIch we feel is working well and shows promise for the future. This is an extensive series of sclentific and technologlcal activitles with Japan at the government-to-government level--cooperative activitles which date back to the early 1960 s.

Historically, I suppose It might be a little difficult to fix a precise date for the beglaning of the Intensifled government-togovernment relationship with Japan. But for the purpose of my remarks, the year 1961 seems to have been the year which witnessed the establishment of a Japan-U.S. Commlttee on Sclentific Cooperation, 
brought about by agreement between the President of the United States and the Prime linister of Japan. Under the terms of this agreement, each government appointed an executive agency to manage its own activities under the arrangement. The National Science Foundation assumed this responsibility for the United States, cooperating, of course, with other key agencies as well as universities and private organizations.

Categories of activities selected covered education in the sclences, earth sciences, planetary and astronomical sciences, biology, mathematics, physical and chemical sciences, engineeriug sciences, and many others. Each side undertook to finance its contributions; no central fund was established for this purpose, nor was any overall joint oversight commission established.

The years following 1961 saw a steady growth of cooperative activity. Each new venture was based on a separate agreenent tailored for the purposes which the two governments had in mind, usually reached at the highest level of government. Accordingly, by 1975 the United States and Japan were carrying out a host of additional activities in such fields as natural resources development, medical research, environment, energy, space, transportation and building technology, and urban affairs. llany of these areas had highly specialized aspects.

The growth of this "special," and in some ways unique, relationship brought its own problems. In the United States alone, 13 technical agencies participated in a wide variety of activities with their Japanese counterpart agencies, provided chalrmen for numerous joint committees and panels, and the Japanese, of course, matched this effort in a complicated internal structure suited to their own needs.

Lacking a single overall agreement with Japan or a single joint commlssion with the responsibility for monitoring and evaluating the expanding relationship, it was felt by 1973 that an overall review of medical, scientific, and technological cooperation between the countries should be made in the light of the broader requirements of the coming decade. The President of the United States and the Prime Minlster of Japan agreed that such a review should be undertaken, and for this purpose, a Joint lievlew ranel was chosen consisting of six eminent individuals (three from each side) who had no direct responsibility for administering existing cooperative programs. Through this arrangement it was felt that they would bring to the review a sense of detachment and overall perspective.

Before the Commission could commence its work, each side had to undertake extensive preparations, which included a careful inventory of all of the bilateral activities in which the two countries were engaged. I was fortunate enough to be asked to serve as the Executive Secretary for the U.S. side of the Panel--a job which I, privately and not entirely facetiously, like to refer to as being the Panel's 
"slave." The Japanese also selected their Executive Secretary, and the two of us began to plan the overall review, the scheduling of meetings, on-site trips and inspections, etc.

At the outset we agreed that while we would take a good searching look at existing programs and past accomplishments and be certain that nothing Important had been overlooked, we would look more to the future and place greater emphasis on future areas of common problems that could be tackled through joint action. The members of the Panel sought to determine how scientific and technological cooperation between the United, States and Japan might be made more responsive to current and future needs.

Having completed our preparations, which involved numerous consultations with all of the technical agencies in Washington carrying out activities with their Japanese counterparts, we scheduled a first meeting of the Panel in Tokyo in early 1975 where the two sides reviewed all known programs in detail, came to some preliminary agreement about relative areas of importance, compared notes on their respective administrative structures, and on special problems.

Once this was all laid out for review, I think everyone was surprised at the extent and variety of this cooperative endeavor. As only one example: The U.S.-Japan Committee on Scientific Cooperation, which I mentioned as probably the earliest activity in a varlety of scientific disclplines, reported that for one program year only (through lfarch $31,1975)$ the level of cooperative activity included 24 sclentific seminars attended by 711 participants; 53 cooperative research projects, Involving 505 participants; 117 visits of scientists to their counterparts in the other country, of whom 73 stayed for periods of longer than one month; a total of 1,236 participants in all aspects of the program carried out under this particular Joint Committee; and 46 publications were produced.

This pattern of activity characterized other programs as well, but I will not attempt to cite all the statistics.

It is obvious, of course, that while statistics of this kind are useful they do not provide a qualitative measure of the value of these programs. So, I w1Il summarize the l'anel's conclusions, which were agreed upon by the two sides after a year of work, very extensive discussions, and visits by each side to many of the other's sclentific laboratories and industrial institutions.

The Joint Panel concluded:

(1) Lenefits had been impressive--"good science" had been conducted, and the programs had developed a healthy, constructive attitude toward bilateral cooperation among key members of the scientific communities of the two countries. 
(2) Eoth countries could Improve the quality and decrease the cost of their scientific research and technological development programs by continuing interchange of ideas and by selected joint activities.

(3) It would be desirable for the two governments to agree on one or more joint research and development efforts in which combined staffs would work together on a specific major project, each contributing in manpower and money in relation to its interests and anticipated benefits. Ubvious savings would accrue from this kind of joint effort.

(4) The existing pluralistic structure was quite adequate to accommodate broadened activity. No basic changes were considered necessary. No "overall umbrella" agreement was recommended, nor any permanent standing commission to oversee the entire program. An independent review should be made each three to five years.

(5) An important conclusion was that more young scientists and researchers should be drawn from industrial laboratories and research institutions.

Looking to the future, the Panel endeavored to identify areas of common interest where agencies of the two governments can continue to work together effectively, and of course, within the limits of their respective budgets. The Panel felt that the range of potential cooperative research effort was very broad indeed. It iclentifled some 20 new areas for cooperative research, which range over environmental and occupational health, nuclear safeguards, clean energy resources, earthquake prediction, transportation, development of new medical tools, food sciences, marine sciences, and research of the sea-bottom, and so on.

In closing, I would like to mention that the Panel recognized that both countries have had experience in advising developing countries on how best to enhance their capabilities in applyine science and technology to development. The Panel did not explore this subject but expressed the view that the two governments should examine the situation to determine whether additional ways could be found to assist other nations in utilizing science and technology for their own development. 

NOTES FROM THE DINNER TALK

BY MR. DANIEL S. GREENBERG, EDITOR AND PUBLISHER

"SCIENCE AND GOVERNMENT REPORT"

(Summarized by Mr. H. Steffen Peiser from a tape recording.)

After an introduction by $\mathrm{Dr}$. E. L. Brady, Dr. Greenberg contrasted his experience in London with his view of the openness to reports of the Washington scene, People here are anxious to obtain public attention; congressmen wish to get their views into the news media. Bureaucrats work with and have even learned to manipulate the press, and for those who are disappointed in a competitive bid for public funds or justice, the press can be an effective court of last resort.

The public, however, does not seek. the news of real science, so scientific news coverage is poor. The first space shots were an exception, but even NASA experiences a declining interest.

By contrast, science policy is news. Science and politics do not understand each other well. Scientists ask of other scientists' statements, "Is it true?" Politicians wonder, "Why is he saying that?" President Nixon's sudden support for cancer research is a striking example of a politically astute but scientifically challengeable initiative. Scientists foresee disasters for lack of U.S. political, industrial, and funding support, in comparison with abroad where some feelings are expressed by comparison with the United States. Mr. Greenberg seeks a balanced view to assure a harmonious relationship between science and society. He hopes for science to provide a realistic picture of what it can contribute to society. He appeals to the audience as members of the scientific community for openness in communicating about reports because of the cardinal importance of science to the well-being of the world.

In a lively discussion, the difficulty of funding long-term goals even when they seemed technically achievable was brought out. The choices that have to be made are intrinsically difficult, and scientists and military advocates are not beyond trying to influence them by startling revelations timed to precede a decisive budgetary decision. The U.S. Congress is very open to advice. Most reporters oppose nuclear energy because they feel strongly that scientists have continually misled the public by understating the significance of unsolved problems. 


\title{
IMPORTANCE OF A STANDARDS MEASUREMENT INFRASTRUCTURE
} IN A DEVELOPING NATION

\author{
by \\ Dr. R. D. Huntoon \\ Consultant and Deputy Director, Ret1red \\ National Bureau of Standards
}

\section{Introduction}

At the time II. Steffen Pelser asked me to prepare a lecture for this occasion, he was himself thinking about a paper he was planning to give at the flrst annIversary of K-SRI--the Korean Standards Research Instltute. H1s subject was "Quant1tative Measurement, the Basis for All Sclence and Technology."*

It was quite natural, therefore, that he should select my subject-"The Importance of a Standards Measurement Infrastructure in a Developing Soclety"--as a possible extension of his thinking. This makes his paper a proper beginning for the analysis to follow, and we quote from 1t a number of Interesting observations made by Mr. Pelser:

1) "The metrolog1st--the specialist sk1lled in making exact observations by quantitative comparisons-has a key role, but measurement alone cannot succeed in the objectives of sclence." I add--unless as frequently happens, he 18 also an active sclentist engaged in the traditional pursults of sclence.

2) "Unfortunately, a metrolog1st has to make another equally Important judgment. Often he w111 find that he cannot be most accurate when he 18 most preclse; nor most prec1se when he 18 most accurate."

3) "In general, do not do too much metrology in terms of defin1tIons directly, but focus on comparisons at or near the h1ghest precision between simllar samples, one of which has the desired attribute at a certifled value closely comparable w1th the second sample."

4) "My conclusion 1s that, In sclence, the metrologist occupies the function which the super craftsman performed in the trades of former years. He 18 a key man; without him you cannot succeed In science, but he should not expect to be seen in the IImelight of greatest fame..."

*Pe1ser, H. Steffen, "Quant1tat1ve Measurement, the Basis for AlI Sclence and Technology," Metrology in Industry and Goverment: How to Find Out Who Needs What Services, NBS Speclal Publication 539, pp. 19-28, Apr11 1979. 
Observation tio. 3 above sounds like heresy coming from a member in good standing of the staff of a national metrological standards

laboratory. Yet in the proper context, for reasons which will emerge, it is a wise and cautious observation with which I fully agree. Before arriving at observation No. 4, Mr. Peiser used some real $11 f e$ examples to make his point: the conservation of parity experiment, the measurements of the atomic welghts of leads by $T$. W. Richards, the discovery of screw dislocations in crystal growth, and the precision welghing of mass standards. These examples lead me to a sorierhat different conclusion than that reached by ilr. Pelser.

I see the course of sclence as a collaborative cooperative develonment between theory and experiment. Sometimes the experiments verify a theoretical leap; sometimes they provide the factual basis for the advance in understanding. In any case, experimental science is founded upon and draws essentially upon preciston neasurements in the laboratory. The metrological infrastructure provides an essential tool to the experimenter, who then proceeds to make creative use of it to achleve his own ends. The conservation of parity experiment is an outstanding example of measurement in a difficult environment. In this case, the experimenters had themselves, as metrologists, developed the state of the measurement infrastructure to the point where this cruclal measurement could be made. They then switched hats, so to speak, and became experimental scientists posing, a fundamental question to nature which could be answered by a measurement.

It is important, however, in this case, and for an understanding of the discussion, to avold confusion between tool and job. Metrolngy is a tool for which one important use is measurement in the experimental laboratory. Others such as mass production of plece parts will occur to the reader.

Thus, metrologists are in a sense toolmakers. They provide the tools for others to use, and as we know, the jobs we can undertake are determined and 11mited by the avallability and sophistication of the tools. It is a confusing happenstance that the metrologist, in developing the tools, also works in the laboratory making measurements to determine the capability of the tools. This metrological infrastructure, which is of concern to us, must be assessed in terms of the Important systems of society, their interactions and their dependence upon an appropriate pool of technology, coupled with a metrological infrastructure, 1tself a system of national extent. The scope and Implications of all these interactions go far beyond the intent of this discussion, which must therefore be limited to some general observations which are designed to stimulate further examination of the deta1ls of your own special systems in each of your countries. 


\section{The Systems Point of Vlew}

As has been indicated, use of metrology is to provide the tools for the professional activities of scientists and engineers. Since their work is useless unless the measurements and data can be exchanged freely and compatibly with their colleagues, the provision of the measurement base to all of them inplies the existence of an organizational structure of national scope which we call the national measurement system (iNiS). To understand it and use it effectively, it is helpful to think of it as a subsystem which is part of a larfer system, the society itself. This implies, of course, that the society is macie up of a number of interacting subsystems that are themselves complex systems. We must examine the N:IS in this context.

In this larger context, we will be better able to understand the nature, value, and importance of the IMS. The roles of organizations, measurement stations, and Individuals as elementary subsystem elements will also become more easily described and understood. Once we accept this approach to my assignment as one which offers the best hope of basic understanding, we see the vast extent of that assignment and the need within the compass of a single lecture to limit my scope to the description of principles at work. Lach of you will then have to apply them in your own nation as a special case. You will le enriched by the exercise in the form of a better understanding of how to plan for appropriate development of your own subsystems. It is far better that way than for an outsider like myself to provide a detalled plan. Only natives who really know your national systems, mores, customs, values, and goals will be in a position to think things through. Iven though well meaning, the overenthusiastic outside expert may well deliver more harm than good. I am sure each of you can bring to mind examples of such mistakes which should convince you of the truth of. this observation.

\section{Social Systems}

The social systems which comprise a soclety such as ours in the United States fall into two main classes which we call socioinstitutional and soclotechnical. The former are the ones brought to mind when one speaks of the institutions of a soclety. The latter are the technologically based ones. They have been formally recognized in our own lational Academy of Sclences/National Fesearch Councll which has a comission to evaluate and express views on soclotechnical systems. We can best characterize each class by enumerating the subsystems which comprise 1t, without any attempt to present a complete 1ist:

\section{SOML SOCIAL SUBSYSTEMS}

\section{Socloinstitutional}

Religlous, legal-judiclal, governmental, fiscal-monetary, securfty (military, fire, and police), and educational (Including. science and engineering). 
B. Soctotechnical

Food, shelter, communication, transportalon, consumer products, power-energy, weapon development, standards and measurement, sclence, englneering, and weather analysis.

The socioinstitutional systems express the social nature and administrative patterns of the soclety, its values, mores, etc. In a sense, these systems determine or display the needs of the people and arrange for the meeting of such needs. Many of these needs require the development and exploitation of technology in order to satisfy them. They lead us to the soclotechnical systems.

The first elght of the sociotechnical systems listed atove are also commonly called industries, and the remalnder can be called techinical support with the science system taking a special place. It leads and paces often ahead of a recognized need, but it also supports and 1 s at the same time a part of an educational system meeting the social necd for dissemination of knowledge.

Having displayed and classified the subsystems comprising the overall system of soclety, some important observations Immediately follow.

\section{III.a. Interdependence}

There is a natural tendency to think of each subsystem as an Independent ent1ty and to study 1 t abstracted from all of 1 ts interrelationships. A little thought shows immediately the fallacy of this. As we all know from sad experience, the working of the fiscal monetary system coupled with the governmental system determines in great measure what can be undertaken and accomplished in the educational system, and the religlous system sets bounds on the very nature of the undertakings.

A more detalled example of more IImited scnpe, but with important bearing upon our interests, is found in those socleties which operate upon the understanding that government service employees should get a major portion of their income direct from satisfied clients. The establishment of a satisfactory functional measurement system in such a soclety, without some fundamental change in this understanding, seems practically impossible to those of us familiar with the worlings of our own iNis.

Many more examples could be eas1ly found, and I am sure each of you can bring some to mind which demonstrate the close interdependence of the socioinstitutional and the sociotechnical systems. We can sum it up by observing that there is tight coupling between and among the systems. 
III.b. Interlocking Components

A little thought indicates that the following statements apply:

1. The subsystems we describe have no clear boundaries between them.

2. Horeover, other listings with other names would be fust as effective in describing the social system of our soclety.

3. Each of us is an elementary component of each subsystem; each constrains or stimulates our Individual actions in some degree.

4. Any one system cannot be changed without a corresponding change in the other, if for no other reason at least because the comon elements function in both systems. A developing society setting out boldly to change one subsystem should not be surprised by changes in another.

III.c. Coupling Coefficients

Every system 1dentified here can be considered to have a coupling coefflclent to each of the others, and even the lower level subsystems have coupling coefflclents to other subsystems. Some coefficients are strong, some weak, and some may even be negative. The resulting complexity seems overwhelming, as indeed 1t 1s. Yet there are ways of approach which in some cases lead to useful analysis.

The Leontleff input-output matrix gives numerical values of useful validity among the industrial systems and their components as Identified in the Standard Industrlal Code (SIC). The transactions matrices prepared by Dr. Raymond Sangster of NBS descrtbe the coupling coefficients of the INIS to the SIC components. This may be useful in estimating roughly the cost effectiveness of measurement undertakings as seen by those systen components. You may thus optimize the cholce between alternative projects in the face of $11 \mathrm{~m}$ ted resources.

\section{III.d. Pool of Technology}

Perhaps the most striking and important observation that comes from looking at this whole set of coupled subsystems which comprise the soclety (the overall super system) is that all the soclotechnical systems and many of the socioinstitutional systems contribute to and are at the same time nurtured by a vast pool of technology. This pool is a kind of storehouse contalning all past technical developrents which, if accessible, can be drawn upon for the support of nev developments, the malntenance of currently used ones, and as a source of Ideas and devices for new applications. 
Th1s pool consists of:

- Information and methodologies

- Facilities in being

- Skilled personnel

- The vast market of technical products

- Communication and mechanisms to provide for Its availability

Of the many characteristics of the pool, two are pertinent at this phase of the analysis.

1. The pool is, and should be, national in scope and avallable to all the society. An 1mportant function of the patent subsystem, for example, is to encourape and enhance this national avallability. A mafor fraction of each nation's pool should be avallable as a sort of world pool to serve similar purposes worldwide.

2. The status, health, avallab1l1ty, and utillzation of this pool both reflects and determines the state of sophistication of the national sociotechnical systems, and in an important way, the socloinstitutional systems.

IV. Implications of the System Structure

IV.a. Continuing Process

The development process for Industrial-technological socleties is a continuing one with no terminating state. In fact, the natural tendency seems to be one of almost exponential growth. The larger the base of technology, the greater the activity and the more possibilities for more innovation. This sequence leads to an everincreasing expansion of the base. The so-called developing nations are embarked upon a course already traversed by some nations, but all are traversing the same route toward simflar goals, and all must be concerned with similar system problems at differert levels of complexity. However, the newer nations have the potential of achieving faster progress by learning from the nations that have previously traversed the same levels. This accelerated growth is often endangered by the danger, real or imaginary, of losing a national Identity.

\section{IV.b. harmonized Development}

The tightness of the coupling among systems discussed earlier implies that they should develop together in a sort of mutual harmony, Each system, if it develops too rapidly, becomes constrained by the inadequacies of associated systems. Pressures develop to speed a matching development in these associated systems. It is the 
responsibility of national planning to ensure that all systems develop together in a somewhat harmonized way.

In our U.S. soclety, these harmonizing forces have been at work without much natlonal consclousness or awareness, because of our constitutional background and 1 ts basic Interpretations allowing, for checks and balances. This soclal system typlcally operates only by permitting delays which appear unacceptable to most developing countrles. An 1nteresting problem arises when a nation in a hurry decides to set national goals for the enhanced development of one of Its major systems by a sudden Infusion of technology, without the corresponding development of assoclated systems that would have transpired in the slower harmonlzed evolutionary process. This has been called leapfrogglng. Harmonization processes become broken down, and mismatches are sure to develop with unexpected consequences.

In these c1rcumstances, It is natural to call upon one or more of the nations with more advanced development for consultation. However, the1r "experts" have matured with systems during harmonized evolutionary development. They w1ll have no experfence with leapfrogging development, so thelr "advice" may well exacerbate the dislocations due to the non-evolutionary development created by the Infusion of advanced technology.

These considerations definftely apply to the standard infrastructure. Attempts to speed development of the IMS by sudden Infusions of speciflc technology can lead to disappointment and even fallure if attention is not given to the Interaction with closely associated soclotechnical subsystems.

IV.c. Layering of the Pool

When we trace the beginnings of our pool of technology, we see first very elementary technologles: manufacture and use of plowe, bricks, na1ls, screws, etc.

These now seemingly simple products of technologies continue to be produced for consumption in the marketplace supplying all systems so long as they $f 111$ a need In competition with newer or higher quality products. Most 1mportantly, the elementary products serve as a basis for more complex technologies, which require them as a basic starting point.

Products of more complex technologles in turn f1l1 market needs and make $1 t$ possible for the development of st11l more sophisticated technologies. The process 18 repeated over and over in the course of t1me, leading to a pyramidal structure of technologles in layers of complexity and sophistication. Each layer draws upon the technologies of earlier layer finding thelr existence necessary to the development. Consider, for example, what we call the vacuum tube technology, which 18 already unable to malntain itself In the 
marketplace. It depended upon the existence of a glass technology, vacuum technology, alloy technology, and metals fabrication technology. These in turn are based upon extractive metallurgy, mining, precise measurements, (for instance, of chemical composition, temperature voltage, current, etc.) transportation, communication, and so on.

The process also involves returning to the earlier technologles to redevelop them into more complex, more efficient ones. Minins, technology, for example, 18 far different now from 1 ts state of development a generation ago. Leapfrogging by an infusion of a new technology creates difficulties when support1ve technologies are not present in the local pool. Arrangements have to be made also to import the underlying technologles or continue to draw upon help from other nations. Less developed countrles need to make careful, farsighted decisions to determine whether to buy the necessary products or to Import an Indigenous technology.

Leapfrogging, the forced acceleration of one subsystem in a developing. nation's development process, is a highly complex process not to be undertaken 11ghtly. It involves a periodic follow-up of infusions of additional help to correct deficlencles not apparent at the outset. Yet the pressures to try to leapfrog rather than to accept slower evolutionary processes of development are tremendous. The rewards in standard of living seem so great, the national vitality is stimulated by ambitious goals, and the pride of achlevement of a high technology Is a significant factor even when the cost was too high for short-term economic benef1t.

\section{IV.d. Scope of Systems}

The nature and benefits of the soclosystems are such that they tend to expand to encompass the whole soclety. Think of the benefits of a communication system or transportation system that covers the whole country (or the world). All those outslde want to foin in when feasible. Moreover, economies often can be achieved by enlarging, the scale. Thus, these soclosystems need to be natlonwide to be fully effective, but we need not plan 1 t that way when a technology is first introduced. So, we find that they w1ll become nationwide as a result of Inherent pressures. There is no need to force the growth from a modest start.

All such growth requires as a fundamental necesslty the development and use of standards, the arrangements by which agreement is reached about the sizes, configurations, and processes for realization of the technological products or services to be supplied to the marketplace from the pool of technology.

These agreements are reached on the basis of physlcal measurements and are expressed in terms of them. Measurement is the language which makes standards possible, useful, and veriflable. In fact, it is so 
essentlal that we have identified the measurement infrastructure as one of the soclotechnical subsystems characteristic of a technologically-based soclety from its outset to development.

IV.e. Awareness

Educational preparation of the system users is essentlal to 1ts full utilization. This is particularly true for the infusion of a sophisticated measurement system and infrastructure. Unless measurement awareness is developed, the new system w111 languish while the potential users proceed with their habltual ways of doing things, with damaging economic loss as a common consequence.

Growth of the system requires fam1liarity and awareness of opportunity. The user must become famlliar with 1ts capab1lities to sense how he can apply it to do things habltually done by less effective means and how he can undertake new things never before practical with the old tools. Awareness starts utilization. As creativity is applied, new applications emerge to bring additional growth and awareness. Therefore, when leapfrogging 18 attempted, careful attention must be given to user awareness.

Surprisingly, there is a danger to a sound utilization of a system. Habitual patterns of utilization develop and then of ten lead to a tendency to take 1 for granted. Calls upon the system may then become unthinkingly automat1c. In this process, the 1mportance of nurturing and 1mproving the system tends more and more to be neglected.

There 1s yet another danger in false ut1lization of a subsystem. Today in the United States we tend to take the communication system, power system, and yes, the NMS, so much for granted that we recognize their existence and usefulness only when they fall through some form of breakdown which curtalls the serv1ce. We have grown to expect these systems to function rellably all the time. When they fall, the entire socloeconomic system seems in jeopardy.

\section{Extended Look at the Pool of Technology}

We now turn attention to further general observations and 1mplications of the pool of technology orfented to demonstrate some aspects of the measurement-8tandards infrastructure. We have already noted that the pool must be at least national in scope if the system utilization is to Involve the whole soclety, and that use and awareness contribute to the growth of the pool. They lead to a positive feedback, which implies exponential growth, with two maln components: awareness for exploitation and Innovation by user creativity and span of coverage with opportunities to stimulate more 1deas and Innovation. Lach effective Innovation becomes an addition to the pool of technology to increase its content. 
An inportant benefit that accompanies the pool of technology in an industrial nation is the economy of scale achieved when proper limits are placed upon the diversity of sizes, colors, or other parameters of products so that large quantities of identical itcms can be manufactured. To 1llustrate, consider the case of fasteners. liuts and bolts could be made in an infinite variety of sizes and sliares. Every product might have its own individual fasteners not interchangeable with those of any other product. The logistics of manufacture, supply, and storage would be so complex and costly that Industries would be handicapped from sheer cost considerations. By mutual agreement to make only certain sizes with specified thread dimensions, the logistics become practicable and large-scale. manufacture becomes possible. Development costs for processing. machines can be spread over large numbers, and automation becomes a viable option. The cost per item drops as quantities increase. Agreement upon standards for a product avolds infinite diversity and achieves uniformity across the whole country to provide interchangeability and large-scale market. Labor in most countries is apprehensive of the decrease in labor cost per 1tem manufactured. This fear is unjustified because the salary and wage costs per dollar spent by consumers does not decrease in a higher technology society.

V.b. Measurement Implications

The basic importance of product standards and interchangeability is at the beginning of an understanding of the importance and role of the ivis. Cogent arguments for standardization can equally be made on behalf of manufacturers to assure uniformity of raw materials or on behalf of ultimate consumers on a quantified measure of product life expectancy and performance. Standards are equally needed to prevent part of a soclety from damaging the interests of another. To reach agreement upon product standards (from plece parts to systems) requires quantitative specification of sizes, materials, their properties, and often the processes by which the manufacture is to be accomplished and the methods by which the products are to be tested. Specifications are expressed in terms of measurements of size, of parameters (resistance or ductility, etc.), of materlal properties (density, viscosity, etc.). If this is to lead to interchangeable parts and products, the measurement language, units, and measurement processes must be objective, quantitative, and compatible throughout the society.

The term, compatibility of measurements, is a most 1mportant concept, which we give a very specific meaning in this Nis context. We say that two measurement stations give compatible measurements if they obtain results which differ from each other by only statistically evaluated small amounts when they measure the same thing (measurand). The proper functioning of the sociotechnical systems through the pool of technology requires the presence of a nationwide inis, whose 
function is to provide an infrastructure that will permit the making of compatible measurements everyplace in the nation.

The various soclotechnical subsystems will be no more effective than their means of providing the necessary compatible measurements. If each subsystem has to put its measurement infrastructure in place independently of an MIS, it would not only be expensive but problems would soon arise from the all-important coupling with associated subsystems.

Thus, our systems approach shows the larger scale need for an NiS and its functions. We remember also that all the technological products follow as end items of a sequence we call scientific research, engineering, and development. These three activities should use the self-same measurement language as the baslc means of quantitative expression and communication of ideas, results of investigations and product designs. Aside from minor departures from agreed terminology and measurement units (like barrels of oil and bushels of grain in the United States), technology finds it very natural and convenient to cooperate with the NiS.

\section{Product Standards}

Let us discuss a little further the standards for industrial products to which we can give the generalized name "hardware." They are physically realizable entities made by a man-devised and mancontrolled process from substances and materlals to perform some function for a user. They are to be distinguished from the products of the agricultural, forest, and service industries.

The hardware to be produced is described in terms of plans and processes to be used by the manufacturer. These descriptions or specifications are commonly recorded in writing. These paper descriptions and plans to realize the product we give the generic name of "software." The software of the kind that states agreements to produce and realize standardized products we call product or engineering standards. Thus, the standards are software which when used lead to standardized hardware. These standards are of four important kinds: configuration (agreements about specific dimensions, materials to be used or specific parameters, material properties or even subproducts already themselves standardized) process, characterizations (displayed by the product or substance concerned), and performance (ability to function in a specified manner without restriction on materials or design).

\section{VII. liealization of Standards}

Means must be available for the realization of the standard and of the products it describes. This is where the measurement capability 
enters. We identify eight major steps in the development of a product:

1) Research adds to the body of knowledge from which inventions can be made.

2) Invention concelves the idea for a device which based upon the body of sclentific knowledge will perform some useful and desirable function. (It could itself be a measuring instrument.)

3) Engineering develops the idea into a practical, useful form by repeated measurements of components, performances, configurations, and environments until the device can be fully and quantitatively specified.

4) Production development modifies design to fit the production process making trade-offs between cost and acceptable performance, all based upon quantitative measurement.

5) Setting the standards consists of the determination of the values that must be obtained when the product is tested if it is to be acceptable.

6) Process control and quality assurance is introduced by specified measurements along the stages of manufacture to ensure that the final product will meet final specifications (or is rejected or adjusted before too much costly work is done), all being part of the process.

7) Verification/quality control provides for the product when completed to be measured with respect to all parameters established in the standard for clearance to market. If the measurements are not compatible with those elsewhere in the whole country, the products may be refected by the intended users. The manufacturer therefore has a self-interest in having his measurement stations adjusted, that is, harmonized to the NMS.

8) Narket (pool) acceptance follows when it can be demonstrated that the standard leads to a useful product. A company which adheres to the standard achieves product acceptance by all relevant sociotechnical systems.

In a modern industrial nation such as the United States, there are some 100,000 product standards in the pool of accepted standards. They function through measurement on myriad of products of the sociotechnical systems. The NiS provides the necessary measurement infrastructure. 
VIII. The Compatible Measurement Base

This brief look at the system environment of the MS allows us to state with some understanding the major functional requirements of the measurement infrastructure if it is to fulfill its essential role in the operation of the other sociotechnical systems.

\section{VIII.a. Linformity}

The nationwide span of the other systems in the sociotechnical family requires that the IMS must likewlse span the entire society. Moreover, since our countries interact on the world scene with all other Industrial natlons, there is strong pressure for a worldspanning uniformity in measurement. Th1s means that our own nationwide system must be modifled to fit into a uniform worldwide measurement system (WMS) if we are to be fully effective as part of the worldwide pool of technology serving the soclotechnical systems of the other nations. This world uniformity requirement is responstble for the present U.S. national undertaking despite some misgivings among our cltlzens to become a metrlc nation, since all other technically based nations are now metrlc or in the process of becoming so.

The required uniformity includes:

- The units of measure for all physical quantitles.

- The corresponding physical reference standards.

- Coupling processes to establish measurement chalns.

- Software relating to measurement processes.

- Internationally recognized product standards insofar as practicable.

VIII.b. Ava1lability

The measurement hardware and software must be avallable to all users, who desire 1t, across the soclety. Means to incorporate new members in to the system must be avallable as 1 grows and diversifles. There Is a need for differentlated services at a level of accuracy matched to each realistic need. It also introduces problems in which confidentlal defense systems have leapfrogged ahead of the other domestic subsystems. Spare parts and service functions must then be provided from abroad without end in sight.

VIII.c. Compatibi11ty

Measurements of any given measurand at any measurement station in the system should give Identical results, within approprlate uncertalnties. In other words, the system should provide to every user the ablilty to make compatible measurements sulted to his needs. 


\section{VIII.d. Stab1lity}

By analogy with VIII.c, the measurement of a given measurand at different times should also give identical results within appropriate uncertainties, provided the reference measurand itself did not change with time. In other words, the measurement system must be compatible across time. There are physical constants of nature that are, as far as we know, invariant in time. All modern measurement systems undertake to define and relate units of measure to appropriate physical constants such as the speed of light, the wave lengths of certain atomic sfectral lines, nuclear hyperfine transitions in certain atoms, fundamental crystal lattice spacings, or atomic masses of single nuclides.*

\section{Uaster-Slave Chains}

Briefly, the system works through master-slave chains. Consider the elemental situation of two stations, each of which uses its instruments to measure a given measurand. If they have not previously been harmonlzed, they can be expected to obtain sisnificantly different results, 1.e., incompatible measurements. Some adfustments must be made by either or both stations to achieve harmony. If one of the two stations has already been harmonized with another which is an accepted member of the Mis, the latter is commonly given the role of master and the new station is slaved to 1 t.

It follows that if several stations are harmonized with and thus slaved to a common master, all the slaves of this master w1ll be compatible. If two masters are themselves slaved to a supermaster, then all slaves w11l be compatible. Th1s leads to a hierarchical structure of master-slave chains with a top-naster station for the whole system (for one particular physical quantity such as length, all within a stated range). Such a complete chain is needed for each physical quantity for each range of interest.

It is important to notice that the top master of every chain controls and is responsible for the entire chain. If he is in error, the whole compatible structure is in error. Commonly, the top master resides in a national laboratory and the reference measurands it uses to establish control over the chain are the National Prototype Reference Standards. These are established at the national laboratory to be in accord with the unfformly agreed-upon definition of the unit of measure (meter, kllogram, ampere, second, etc.). Note also that some

* $\Lambda$ more detailed examination and explanation of compatibility w11l be found in "Compatibility in :leasurement Systems," R. D. Huntoon, Report on an NBS/AID/OAS Workshop on Standardization and Measurement Services in Industrializing Economics, NBSIR 75-769, held Nov. 1974. 
stations may be slaved directly to the top master and some through several intermediate masters. The nature of the chain depends upon the economics of the situation and the needs of the user-slave.

When a system is thus coupled to a top master, the responsibility for proper measurement becomes enormous. This responsibility becomes easier to bear if the load is shared in a "round robin" among the top masters of several nations as is now done at the International Bureau of Welghts and Measures (BIPM) established in Sevres, France, by the Treaty of the Meter.

The uncertainty of measurements at a lower slave station can be defined as the uncertainty of a local measurement coupled with those of the successive higher level master stations for a given measurand and with that to be given by the top master for the realization of the unit in terms of the definition (the coupling recommended is the square root of the sum of the squares of the individual uncertainties).

This leads to an interesting anomaly alluded to by Mr. Pelser in his paper referred to in the introduction. A tightly harmonized masterslave chain can yield subsystem compatibility with less uncertainty than that between the standard of the master in the subsystem and the defined unit, thus leading to the situation he describes as "He cannot be most accurate when he is most precise..." and vice versa.

This is a real anomaly. So often, metrologists can and should aim to be far more precise than they can be accurate. For example, in measurements of atomic masses, compatibility of one part in $10^{8}$ has been achleved but the rest mass of the reference nuclide ${ }^{12} \mathrm{C}$ in terms of the kilogram is known only to about 1 part in $10^{6}$. Another example occurs in the measurement of voltage. Compatibility of one part in $10^{8}$ has been achleved by the use of Josephson Junctions, but the knowledge of the volt as maintained by LBS in terms of the definition is no better than some few parts in $10^{6}$ as determined by international comparison at BIPM.

The means by which the NMS makes harmonization avallable to any measurement station vary from physical quantity to physical quantity and according to the needs of the user. They fall into four general categories.

\section{IX.a. Passive Calibration}

The slave sends his instruments or standard to the master where Identical measurands are measured against both master and slave devices to arrive at harmonization adjustments. Infortunately, this older and widely-used mode does not involve the operators and environment at the slave station in the process, and therefore fails to assure measurement control at the slave station. 


\section{IX.b. Active Calibration}

1) The master sends a premeasured measurand to the slave who measures it and reports back and returns the measurand with the results. The master checlis the measurand to be sure it did not change during the trip and sends harmonization adjustments back to the slave. The measurands can be some artifact or a sample of a standard reference materlal.

or 2) The master sends his instrument or standard to the slave who makes comparison measurements on identical measurands. He makes his own harmonization adjustments and returns the master instrument. The master rechecks the instrument to be sure it did not change.

or 3) The slave obtains from the literature the value of an appropriate physical constant or material property. lie then measures. this property at his station and makes his orm harmonization adjustments. This slaves him to the station which measured and published the data. At least one country (Brazil) has considered this procedure to be potentially disruptive of 1 ts iNis, if an in-country laboratory other than the national standards body slaves itself to a foreign master station. It is a law therefore, though in practice not enforced, that unauthorized SRM's must not be used.

IX.c. Absolute

The slave becomes his own master by starting. from the basic definitions to arrive at his own prototype realization of the unit. This is possible in principle for all quantities except mass and those units for other quantities which derlve from it. The mass unit is still defined as that of a particular platinum cylinder, and therefore, mass standards can only be harmonized by direct or indirect reference to 1t. In general, absolute harmonization is less accurate than through a compatibility measurement chain and much more time consuming and costly.

IX.d. Unique

The calibration of clocks and time scales and frequency meters is unique for two reasons. First, time interval measurements nowadays are by far the most accurate measurements that can be made by science. Secondly, by means of radio broadcasts, standard frequencles and time signals are made to cover the earth and become inexpensively available to anyone with proper receiving and recording equipment at accuracies in excess of virtually all contemporary needs.

\section{IX.e. General}

This examination of the compatibility modes is a major functional requirement of the IVIS. With such understanding, one can provide 
hardware, measurands, and software for product standards and measurement processes to the pool of technology as well as for use by all the other sociotechnical systems. These sociotechnical systems evolve along with the NMS with such tight couplings to it that they exist and function only to the extent that the MMS fulfills its functional requirements. This latter statement compresses into one brief sentence the fundamental importance of and the responsibility placed upon the NMS in a technology based soclety. Yet the IMS is generally taken for granted, as it should be if it is healthy and growing. If it fails, tragic circumstances arise with mafor economic consequences or in some other noticeable way.

And now we reach the point for understanding of the observation by Nir. Peiser which I labeled as heresy in the introduction. His question can now be paraphrased in the terms of this system analysis by saying:

Compatibility usually should take priority over accuracy in newly developing systems. The accuracy, as far as it is necessary, can be acquired by harmonization with top masters In other nations which have realized the units from the definitions and reached harmonization agreements via the International Bureau of Weights and lleasures (BIPN).

\section{Human Factors}

The isis infrastructure is dependent upon the human components in a cruclal and unique way. In fact, as w11l become apparent, operator integrity is absolutely essential to successful function of the measurement infrastructure.

\section{X.a. Statistical ilature of ileasurement}

The critical nature of the human component arises from the statistical nature of the measurement process 1tself. Repeated measurements, in what seem to be identical situations, give observably different, $1, e .$, a spread, of results if the precision of the equipment is being fully utilized. So long as the situation is not changed in some material way, the population of measurements shows stable statistical

parameters. In this stable condition, the measurement process is sald to be under control. llowever, the operator himself is an important element in the statistical distribution of the measurements. Changing, from one operator to another of en changes the distribution. Changing physical environments commonly brings changes, too, and experience is a crucial factor in recognizing and avoiding these disruptive changes. Experienced metrologists seem to develop, through continued experience, a sort of sixth sense which tells them if the measuring, system is stable or if some subtle change has taken place. The inexperienced blame themselves, and worse still, wishing to hide their own supposed lack of skill, adjust data to look more self-consistent. 
If the measurement station is functioning properly with operators of integrity and any blas has been recognized and allowed for, the distribution of differences from the mean will be of a random nature, each deviation being independent of the others and Impossible to predict, except in a probabilistic or statistical sense. That is, one can give odds about how large an interval will contain the next measurement but not where it will fall.

\section{X.b. Next Measurement Sequence}

The operator of a measurement station can by repeated measurements assure himself, with readily avallable statistical algorithms, that his measurement station is in control and performing reliably. If, then, he is given another similar measurand and asked to measure its value, he can do so and obtain an answer. But questions immediately arise:

1) How do you know the measurement station did not change since the last measurement?

The answer is that there is no way to tell for sure. A repeat of the measurement or one on a known reference standard will very greatly reduce the doubt but not eliminate 1t. Practical considerations in working measurement stations do not permit the operator to make many measurements of each item. He must rely upon judgment based upon experience and be alert to notice deviations from the expected statistical parameters.

2) Low do you know where this measurement will lie in the expected statistical variations?

There 18 no way to tell from a single observation. The mean of two or several measurements can be used, but this does not reduce the higher level master errors.

3) Ilow do you know that your result is compatible witi the rest of the MMS, 1.e., that another station would obtain the same result on your measurand if asked to measure 1t?

The answer is that my station has been harmonized with an acceptable compatible station of the system within a certain stipulated statistical variation. One can only give confidence intervals, not absolute certainty.

4) llow do you know that your station has not changed in some significant way since the last harmonization for compatibility?

The answer is I do not know and I cannot, but I can arrange for the risk of departure outside the range to be very small. I do know that the pattern of harmonizations indicates stability 
of the station, and I can be, say, 95 percent sure that it has not changed significantly, Also, my experience over time tells me it is still in control.

All the above answers depend upon proper performance of the operator-metrologist--as well as his equipment.

\section{X.c. Human Operator Requirements}

We are now in a position to indicate with some measure of understanding that there are important human requirements that apply to the station operator. The operator must have the requisite education and considerable exposure to measurement equipment sulted to the function of his measurement station, to the maintenence of the equipment, to the software avallable to him, including that from his master station and the rest of the in's, to the capabilities and deficlencies of his equipment, to the expected stability and requirements for reharmonization, and to the whole measurement process rellably operated over a long perfod all to build an awareness of the system within which the concepts of measurement assurance govern his performance on his job. Given these attributes, the operator will function with a quiet but easily apparent confidence. He will not present one system for harmonization and use another. He w1Il not substitute systems, but run the systcm with great care for harmonization and never relax the cortrois for normal operations.

The oferator then can and must be trusted to obtain honest harmonization and not use another system or arother set of criteria. The whole structure and its effective operation clepend upon the integrity and long-term rellability of the opcrators of the measurement stations which comprise the network.

Staffing a measurement system, therefore, with station operators who meet all of these human requirements is no mean undertahing. Even then $1 t$ is impossible to avold all nistalies; judgments will not always be correct; lapses will occur. Jut if the interest is there and the staff is always willing to search for one amother's errors and acknowledge their own, problems will become self-correcting.

There are external requirements, too. iefther the soclal order nor the governmental systems must reward cover-up of errors fallure. Evolutionary growth can then be expected to reap the rewards of a successful system.

liere again we see the interplay of checks and balances which characterize the harmonlous evolutionary developient of a set of closely coupled soclotechnical systems. A sudien infusion of measurement technology into a nation, whose other sociotechnical systems and socioinstitutional systems do not yet offer the requisite awareness needed to maintain the measurement system in 1ts suddenly augmented form, can generate problems which reduce the revards, 
Disappointment is 11kely if the evolutionary process is hurried too much. Careful planning and understanding of what to expect will allow a maximum pace of the advance.

XI. Final Observations

Let us look back over the plcture in large perspective to "wrap up" our present understanding.

he have seen:

a) That the measurement infrastructure in the form of a soctotechnical system exists in our soclety as one of a set of tightly coupled systems.

b) That all these systems contribute to and draw upon a ponl of techrology which is a common part of all of them.

c) That the NIS provides the following, all-important services for the use of all the other systems which comprise the soclety:

1. Software about measurements.

(a) liescriptions of and standards for measuring instruments.

(b) $\Lambda$ structure to permit harmonization of al1 measurement stations.

(c) Coupling to the world measurement system.

(d) Education for metrologists.

(e) Working language of quantitative nature for interchangeability in the pool, which consists of formulation of specifications and standards for Industrial products, process control to give manufacturing, capab1lity and quallty assurance, and verification that specifications have been met so that quality policing is effective.

2. Promulgation of measurenent awareness and relevant informat1on:

(a) That this language and hardware of measurement are essential to the functioning of all the systems and for the 1nterchangeability of parts and processes which makes the pool of technolory useful on a nationwicle basis.

(b) That compatibility across space and time is the foundation stone of the MS. 
(c) That Mr. Peiser's heresy is well founded, that is to say, that under some clrcumstances 1 t 1 s best to strive for optimum precision even at the expense of accuracy.

(d) That all systems should cvolve together in harmonious evolutionary development.

(e) That sudden infusion of technology to speed up unduly the process of development in one sector or system may serlously disturb the equilibrium of joint evolution. Careful plans must be lald to handle the expected problems in any unevenness of the evolution of systems. The iMS is especially sensitive in this regard.

In short, we could paraphrase the old adage "For want of a na11 . . ." to read:

For want of compatibility the measurement was lost, for want of the measurement the products were faulty, for want of confidence the company falled, for fallure of companies the industrial development falled, for want of systems the country reverted to a nonindustrial, poverty-stricken, isolated agrarian soclety.

Hence, we can sum up the Importance of the NiS as "no measurement system, no industrial soclety as we know 1t." 


\section{EVALUATION OF THE NBS/AID WORF.SHOP \\ ON STANDARDIZATION AND MEASLREMENT SERVICES, 1978}

A. RELEVAIICE TO YOUR PROGRAMS III YOUR COUNTFY

1. What portion of the presentations had any relevance to your

a. present need 8 ?

AL-IHLLAF: Measurement, I1brary.

CHANDRA: ANSI, NBS Overvlew, Natlonal Englneer1ng, Laboratory, National leasurement Laboratory, National Technical Information Service, Sclentific Atlanta, lexas Instruments.

DE CHLAN: First week of Workshop.

FADLALLA: INBS.

GANDI: NCSL, NBS, Seminar, New York, Litlanta.

HALTEH: NBS and other specialized organizations.

KIM: National Englneering Laboratory of NBS.

LAINRENCE: Library and Information Service, organization and operation of AirSI and sister organizations, dealing with practlcal development of standards through laboratories, research.

YIZZA: Accuracy ratio (NCSL Conference) and visit to AC-IC difference laboratory.

OWINO-OKWLRO: Laboratory fac1l1ties for metrology, approprlate technology for industrialization in developIng countries, standardization and callbration.

QURASHI: Sess1ons I to IV of NBS/AID/LNCSTD Seminar.

RAJARAMAN: ANSI, NBS Overvlew, Heasurements, Englneering Laboratory, Technical Information Service, Library Information Service, visits to technical institutes and Industrial units.

SULIMAN: NBS presentation.

TUDOR: Basic concepts of all vistes, in particular, iacy's.

WAENY: NCSL, ANSI, Ilacy's, Texas Instruments, Johnson space Center, laryland Welghts and Measures, TAPPI. 
b. future needs?

AL-KHALAF: Research and development.

CHANDRA: Inst1tute for Computer Sclences and Technology, computer operated machine tool shop.

FADLALLA: NBS.

GANDI: NCSL, NBS.

HALTEH: Laboratory fac1lities.

KIM: Institute for Computer Sclences and Technology, Library Information Service.

LAWRENCE: Advanced technology.

MAZZA: Measurement assurance programs.

OWINO-OKWERO: AIl lectures and visits to Industrles,

QURASHI: Sessions V to VII of the NBS/AID/UNCSTD Seminar.

RAJARAMAN: Macy's, Institute for Computer Sclences and Technology, Sclentific Atlanta, Texas Instruments, UnIversity of Alabama, Instrument shops.

SULIMAN: Nearly all.

TUDOR: NBS equipment.

WAENY: NBS, other laboratories, universitles.

2. Wh1ch presentat1ons could have been om1tted

a. at the National Conference of Standards Laboratorfes?

SULIMAN: Workshop sessions.

WAENY: Legal metrology.

b. of the NBS presentations?

- AL-KHALAF: Tour of bas1c research laboratories.

CHLANDRA: Cooperat1ve Technology, 
c. at the Seminar, "The Technological Knowlege Base for Industrializing Countries"?

CHANDRA: Experience of a major U.S. firm in a newly industrializing country; the role of licensing. negotiations.

GANDI: National and international standards that must be satisfled by industrializing, countries.

LAWIENCE: Historical and non-practical proposals, highlight trends.

IAZZA: Knowledge required to enable a country to acquire commercial, industrial technology.

WAENY: Short, sketchy presentations.

d. In New York, Atlanta, Birmingham, Dallas, and liouston?

CHANDIA: TAPPI, :lolecular Blology and Cell Culture at University of Alabama.

CANDI: Nacy's, Sclentific Atlanta, Southern Kesearch Institute, Lniversity of lexas.

IUZZA; TAPPI, liealth Center in Birmingham.

SULIYAN: Liniversity of Texas.

TUDOR: Birmingham and lallas presentations.

3. Which presentations could have been expanded

a. at the National Conference of Standards Laboratories?

GANDI: Accreditation, enforcement and monitoring of laboratories.

RAJARAIAN: Accreditation of laboratories with reference to International development.

TUDOR: Measurement assurance pro,ram, legal metrology.

WIENY: ieasurement assurance programs, accuracy ratios.

b. of the INBS presentations?

AL-KHALAF: Library tour.

CHLANDRA: Nat1onal Neasurement Laboratory, National Engineering Laboratory. 
DE CHAN: Dr. Huntoon's presentation.

GANDI: All.

KII: National Englneering Laboratory.

OWINO-OKWERO: Quality control, process control.

LAJARANAN: INBS help to developing countries for metrological needs, basic and conventional calibration services.

SULIMAN: National Neasurement Laboratory, Library Information Service.

WAENY: IJBS Internal measurement assurance program.

c. at the Seminar, "The Technologlcal Knowledge Base for

for Industrlalizing Countries"?

AL-IHALAF: Short contributions, discussion time.

DE CHAN: Dr. Qurashi's presentation.

HALTEH: Three days needed.

LAWIENCE: Workshop participants' presentations.

OWIiO-OKJIERO: Trade agreements, training technical managers, Industrial engineering.

QURASHI: Sessions IV to VII.

IAJARAMAN: Experiences of U.S. corporations in developing countries.

SULIMAN: TIme too short.

TUDOR: Presentations of delegates from developing countries.

WAENY: Group papers.

d. In New York, Atlanta, Blrmingham, Dallas, and Hlouston?

AL-KHALAF: ANSI.

CHANDRA: ANSI.

UE CHLAN: Macy's.

GNNDI: AISSI. 
LAWRENCE: Texas Instruments.

SULIMAN: Southern Research Institute, University of Alabama, and Texas Instruments.

TUDOR: Johnson Space Center.

4. Which presentation was most valuable for you

a. at the National Conference of Standards Laboratories?

GANDI: Measurement assurance program, accreditation of laboratories.

MAZZA: Accuracy and accuracy ratios.

RAJARAMAN: Measurement assurance program, training of personnel for metrological needs.

TUDOR: Measurement assurance program.

WAENY: Heasurement assurance program and accuracy ratios.

b. of the NBS presentations?

AL-KHALAF: Library, applied research.

CHANDRA: National Measurement Laboratory, National EngineerIng Laboratory.

DE CHAN: National Measurement Laboratory.

FADLALLA: A11.

GANDI: AII.

HALTEH: All.

KIM: National Engineering Laboratory.

LAWRENCE: Overviews and laboratory visits.

MAZZA: Measurement assurance program.

RAJARAMAN: National Measurement Laboratory, National Englneering Laboratory.

SULIMAN: All.

TUDOR: Solar water heating.

WAENY: All, especlally Dr. Huntoon's presentation. 
c. at the Seminar, "The Technologlcal Knowledge Base for Industrlalizing Countries"?

AL-KHALAF : AII.

DE CHAN: Dr. Qurash1's presentation.

FADLALLA: All.

GANDI: Dr. Somer's presentation.

HALTEH: AII.

LAWRENCE: Those of a non-histor 1cal nature.

MAZZA: Dr. Lee's presentation, "H1gh Technology Qual1ty Control in a Newly Industrializing Soclety."

OWINO-OKWERO: Industrial engineering and investments.

QURASHI: Keynote and Sessions II and III.

RAJARAMAN: Knowledge required for Industrial quality control.

SULIMAN: AIl.

TUDOR: Dr. Qurash1's presentation, "Management of Development of Technical Knowledge In Pak1stan."

WAENY: All keynote speakers.

d. In New York, Atlanta, B1rmingham, Dallas, and Houston?

CHANDRA: ANSI, Sclentific Atlanta, University of Alabama, Texas Instruments, Johnson Space Center.

DE CHAN: Macy's, Georgla Institute of Technology, Southern Research Inst1tute, Texas Instruments.

GANDI: ANSI, Georgla Institute of Technology, University of Alabama, Texas Instruments.

LAWRENCE: Macy's, Georg1a Inst1tute of Technology, Southern Research Inst1tute.

MAZZA: Sclent1f1c Atlanta, Texas Instruments, Johnson Space Center.

OWINO-OKWERO: Research and development for Indigenous services (e.g., electrification systems), Georgla 
Inst1tute of Technology, development of new drugs (UAB), both visits in Dallas.

QURASHI: Georgla Institute of Technology, University of Alabama, Texas Instruments.

RAJARAMAN: ANSI, Sclentific Atlanta, University of Alabama, Texas Instruments, Johnson Space Center.

SULIMAN: Macy's, Georg1a Institute of Technology, Scientific Atlanta, University of Alabama, Southern Research

Institute, Texas Instruments.

TUDOR: New York and B1rmingham presentations.

WAENY : All.

5. What presentations could have been added?

CHANDRA: Visit to NBS/Boulder.

DE CHAN: Sears Quality Control Department.

KIM: ASTM.

RAJARAMAN: NBS/Boulder, ASTM.

TUDOR: TIme and frequency.

6. General comments on the overall benefits of this Workshop to you and your country.

AL-KHALAF: The Workshop in general was very beneficlal. It is very Intensive which sometimes caused inconvenlence. Since the program detalls are prepared ahead of time, the partic1pants should be given a chance to choose some parts of 1 t which are of interest to them.

CHANDRA: The Workshop has given an opportunity to overview the present system of standardization and measurement services In the United States and also some 1dea about the on-going advanced research programs in several areas.

DE CHAN: Gave me and my country the whole view of the measurement and technological progress in the United States. There was good contact with persons and institutions.

FADLALLA: Although the program showed us highly sophisticated research and instruments, yet it clearly demonstrated to me the future planning of my work. The program also revealed that even the United States could be faced by 
problems which may be of special interest to developing countrles. The way such problems are solved is very important to us.

GANDI: Seelng the voluntary system in operation; broadening the view Into the problem; and access to information base.

HALTEH: It glves a general plcture about all the activities of standards work and legal metrology as well as measurement and calibration. In general, it is a very good program.

KIM: Th1s Workshop has given me a greater knowledge base professionally and technically. Applying the knowledge thus acquired to my practlcal work, I belleve I could make a contribution towards technical improvement and development in my country. This Workshop reminds me of the proverb: "Seeing 18 belleving."

MAZZA: I have established contacts with the NBS staff, and I have an Idea about how and In what they are working now.

OWINO-OKWERO: Experlence on how to cover and carry out activ1tles of standardization, especlally involvement of Industry, government, university, and other organizations. Also, that an efficlent communication system is a major facility in meeting this level.

QURASHI: Certalnly provides insight into the applications of standards and quality control procedures and their management.

RAJARAMAN: Coming as I do from a developing country with a new Bureau of Standards which looks forward to International assistance for the 1nitlation of 1 ts work program, I feel that the Workshop has enabled me to appreclate the role NBS can play for the bullding of the standards body through USAID.

SULIMAN: There 18 no doubt that I have benef1ted from the Workshop greatly technically, and 1 w wll be of great help to me in my work in the fleld of standardization or in Industrialization. It was Indeed a great chance to attend the Workshop at this time as we are now trying in Sudan to evaluate the standardization work and reorganlze the Department.

TUDOR: I am sure that the Workshop has furnished excellent guldeIInes on setting up a Measurement Service at BNSI.

WAENY: Very Interesting, very helpful, and informative for all connected with metrological work. For my specific case, it allowed further opportunity to question on MAP's and SRM's. 
B. PERSONAL QUESTIONS

1. Did you

a. enfoy the Workshop?

All answered yes.

b. regret attending the Workshop?

A11 indicated no.

2. Did you profit professionally and technically?

All answered yes, although two indicated professionally only.

3. Do you feel you have established personal and useful contacts with

a. NBS staff?

All answered yes, except one person who reserved judgment.

b. other U.S. colleagues from the States?

Eleven persons answered yes, two no, and one reserved judgment.

c. other Workshop participants?

All answered yes.

4. Do you feel your country should have sent someone else of

a. greater position seniority?

Two persons answered yes, six no.

b. lesser position seniority?

Two persons answered yes, five no.

c. greater technical experience?

Two persons answered yes, six no.

d. lesser technical experience?

One person answered yes, five no. 
5. What suggestlons would you make for the poss1ble organ1zational arrangements of future NBS/AID programs?

AL-KHALAF: 1. Increase the services you offer to participants (1.e., plck up at alrports, employ better means of transportation--especially in the New York part of the program).

2. Divide your tours Into two groups according to the cholce of participants. Th1s has the advantage of decreasing the load on particlpants and giving them the cholce of seeing what they want to see.

CHANDRA: The presentations may have been more exhaustive in some selected areas. Moro time should have been allotted to visits to the laboratories, and presentations could have been made there. Fewer lectures and more v1sits would be desirable.

DE CHAN: The organization of th1s Workshop was wonderful. I think that it couldn't have been better.

FADLALIA: The course, although very well organized, had too many long days of work that fatigued the particlpants, making 1t cumbersome to them. It 1s suggested that in the future you cut the number of hours and perhaps allow some free t1me in the evenings.

GANDI: 1. U.S.-Indones1a agreement for sclentific research and technological development be materialized.

2. More contact w1th Indonesian Embassy, e.g., Industry cultural division.

3. Arrangement for possible access to NBS Information base.

HALTEH: The last four days of the program were very crowded in activities and travel; elther extend the perlod of time for the same activities or cancel some of the program wh1ch 1s not directly related to the standardization activities.

RIM: It would be much better if the number of participants could be reduced to 10 .

LAWRENCE: Present organ1zational arrangements were good. Any Inconvenience I suffered was due to my not having traveled sufficlently light as was advised by NBS.

MAZZA: To extend the time for the visits out of Washington (NBS) 
and, for Instance, to travel once each two days with only two presentations for each day.

OWINO-OKWERO: 1. For personal convenlence, partlclpants should have at least 48 hours at every station of visit.

2. More time for discussions.

3. Although 1t is required that participants must know English, standardization has no such barrler, and I think colleagues from French-speaking Africa should also be Invited.

QURASHI: It would be a help for more Informal contacts if an occasional afternoon could be left free durlng each week of the Workshop.

RAJARAMAN: The program should beforehand Indicate the flexib11Ity of accommodating 3 or 4 days' duration of the visit at a place of his speclal Interest and particular needs (relating to standards work).

SULIMAN: The tour in the States was very useful and Important, but living could be made easier if all participants could return to Washington (NBS) and hold the closing session there before golng home.

TUDOR: A little more time in between presentations should be provided to grant participant a chance to explore in greater depth areas of particular interest.

WAENY: Try to restrict the range or divide Into varlous groups, as for example:

a) Basic mechanical and electrical

b) Industrial measurements

c) Basic standardization and traceability to primary standards

d) $\mathrm{MAP}^{\prime} \mathrm{s}$ and $\mathrm{SRM}^{\prime} \mathrm{s}$ accuracy

e) Industrial standardization

f) Measurement and standardization in other areas (chemistry, etc.)

g) Other advanced measurements in different areas

h) Quality control, quality assessment, and other related areas

In some cases, a course (formal) would be interesting and a prerequisite could be established. For example, a spectal case-MAP's, where in two or three weeks could be covered: 
a) Basic statistics and error analysis

b) Accuracy and ratios

c) Traceability

d) Design of procedures and experiments

e) Establishment of routines

f) Establishment of controls for computer program

(A minimum of previous reading should or could be required.)

\section{OTHER COMMENTS}

CHANDRA: Excellent arrangements were made.

DE CHAN: The only problem is that if possible, give us more time to better analyze and understand what has happened day by day.

Thank you very much.

FADLALLA: In general, the Workshop was very useful. I liked very much the Seminar and 1ts timing. Again, I would like to stress the necessity of cutting the number of hours per day to allow a little free time for particlpants.

My thanks and appreclation to the NBS staff for the excellent arrangements and dedication shown to us.

GANDI: More free time desirable during the program for studying documents and seelng the people of the United States.

KIM: Three or more presentations in a day are apt to exhaust participants, especlally when you consider the participants are travelers abroad.

MAZZA: I appreclate very much what you have done for me and my country.

OWINO-OKWERO: NBS/AID should recommend the establishment of standardization organizations to countries which do not have such organizations since the effect, by way of trade, w111 benefit both countrles.

QURASHI: Some of the field visits were very llluminating and instructive. The breadth of the topics represented was satisfying.

RAJARAMAN: The Workshop has been well planned and thoughtfully prepared to have the optimum utilization of time and resources spent by the participants and NBS staff in the characteristic American way of $11 f e$. 
SULIMAN: 1. I think the Workshop was very well organized and planned, but it will be of great use if some visits to industries are included. This will give a good Idea of how the standards prepared are used or implemented in practice.

2. It would be useful to have some presentations from expert industrial personnel who could talk about quality control systems in their production units.

TUDOR: NBS perhaps could develop a program by which developing countrles may be informed of training possibilities at varlous levels and in differing flelds at NBS. 

NBS-114A (REV. 0.78 )

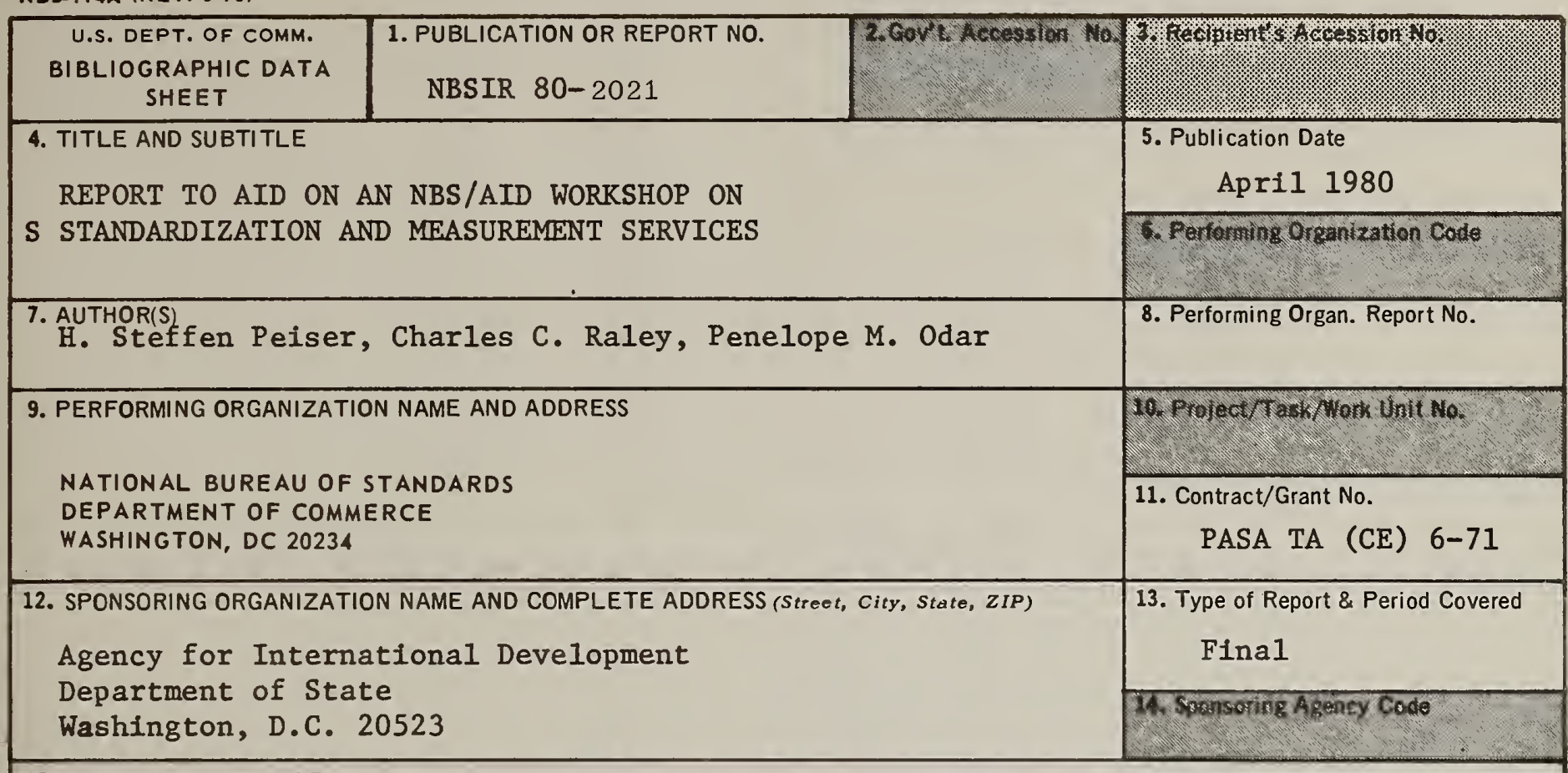

15. SUPPLEMENTARY NOTES

Document describes a computer program; SF-185, FIPS Software Summary, is attached.

16. ABSTRACT (A 200-word or less factual summary of most significant information. If document includes a significant bibliography or literature survey, mention it here.)

From October 3-21, 1978, a Workshop was held at the National Bureau of Standards, Gaithersburg, and at selected universities, research institutes, standards developing organizations, test centers, and industrial companies, under the sponsorship of AID. The object of the Workshop was to give standards officials of industrializing nations insight into the standards and measurement systems of the United States and the role of the National Bureau of Standards, so that these officials might consider what parts of the U.S. system might usefully be adapted to conditions in their home countries. In addition, the participants had the opportunity of attending the National Conference of Standards Laboratories and a special seminar designed to assist the preparation for the U.N. Conference on Science and Technology for Development (UNCSTD). During the Workshop, papers were presented to exchange standardization experience from each participant's country. (These papers were previously published in NBS SP-543, the report on the UNCSTD seminar.) The presentations of the special evening speakers for the Workshop are featured in this report and also a special contribution by the representative from the Arab Organization for Standardization and Metrology. The other participants were from Argentina, Barbados, Brazil, Guyana, India, Indones1a, Jordan, Kenya, Korea, Pakistan, Panama, Saud1 Arabia, Sudan, Tanzania, and Tunisia.

17. KEY WORDS (six to twelve entries; alphabetical order; capitalize only the first letter of the first key word unless a proper name; separated by semicolons)

AID; assistance; developing economies; foreign relations; industrializing nations; international relations; LDC's; measurement services; standardization

18. AVAILABILITY

$$
\text { X Unlimited }
$$

For Official Distribution. Do Not Release to NTIS

Order From Sup. of Doc., U.S. Government Printing Office, Washington, DC 20402, SD Stock No. SNO03-003-

[X] Order From National Technical Information Service (NTIS), Sprịngfield, VA. 22161

\begin{tabular}{|l|c|}
\hline $\begin{array}{l}\text { 19. SECURITY CLASS } \\
\text { (THIS REPORT) }\end{array}$ & $\begin{array}{c}\text { 21. NO. OF } \\
\text { PRINTED PAGES } \\
\text { UNCLASSIFIED }\end{array}$ \\
\hline $\begin{array}{l}\text { 20. SECURITY CLASS } \\
\text { (THIS PAGE) }\end{array}$ & 66 \\
UNCLASSIFIED & $\$ 7.00$ \\
\hline
\end{tabular}




